Biogeosciences Discuss., 6, 5461-5505, 2009

www.biogeosciences-discuss.net/6/5461/2009/

(C) Author(s) 2009. This work is distributed under

\title{
Mapping landscape scale variations of forest structure, biomass, and productivity in Amazonia
}

S. Saatchi ${ }^{1}$, Y. Malhi ${ }^{2}$, B. Zutta ${ }^{3}$, W. Buermann ${ }^{3}$, L. O. Anderson ${ }^{2}$, A. M. Araujo ${ }^{4}$, O. L. Phillips ${ }^{5}$, J. Peacock ${ }^{5}$, H. ter Steege ${ }^{6}$, G. Lopez Gonzalez ${ }^{5}$, T. Baker ${ }^{5}$, L. Arroyo ${ }^{4}$, S. Almeida ${ }^{7}$, N. Higuchi ${ }^{8}$, T. Killeen ${ }^{9}$, A. Monteagudo $^{10}$, D. Neill ${ }^{11}$, N. Pitman ${ }^{12}$, A. Prieto $^{13}$, R. Salomão ${ }^{7}$, N. Silva $^{14}$, R. Vásquez Martínez ${ }^{10}$, W. Laurance ${ }^{15}$, and H. A. Ramírez ${ }^{16}$

${ }^{1}$ Jet Propulsion Laboratory, California Institute of Technology, Pasadena, CA 91109, USA

${ }^{2}$ Environmental Change Institute, School of Geography and the Environment, University of Oxford, OX1 3QY, UK

${ }^{3}$ Institute of Environment, University of California, Los Angeles, USA

${ }^{4}$ Museo Noel Kempff Mercado, Santa Cruz, Bolivia

${ }^{5}$ Earth and Biosphere Institute, School of Geography, Univ. of Leeds, UK

${ }^{6}$ Department of Plant Ecology and Biodiversity, Utrecht University, The Netherlands

${ }^{7}$ Museu Paraense Emilio Goeldi, Belem, Brazil

${ }^{8}$ Instituto National de Pesquisas Amazônicas, Manaus, Brazil

${ }^{9}$ Center for Applied Biodiversity Science, Conservation International, Washington, DC, USA

Distribution of Amazon forest structure

S. Saatchi et al.

Title Page

Abstract

Introduction

Conclusions References

Tables Figures

14 I

4

Back

Close

Full Screen / Esc

Printer-friendly Version

Interactive Discussion 
${ }^{10}$ Herbario Vargas, Universidad Nacional San Antonio Abad del Cusco, Cusco, Peru

${ }^{11}$ Herbario Nacional del Ecuador, Quito, Ecuador

${ }^{12}$ Center for Tropical Conservation, Duke University, Durham, USA

${ }^{13}$ Instituto de Investigación de Recursos Biológicos Alexander von Humboldt, Colombia

${ }^{14}$ CIFOR, Tapajos, Brazil

${ }^{15}$ Kent University, Canterbury, Kent, UK

${ }^{16}$ Universidad de Los Andes, Venezuela

Received: 19 December 2008 - Accepted: 3 March 2009 - Published: 4 June 2009

Correspondence to: S. Saatchi (saatchi@jpl.nasa.gov)

Published by Copernicus Publications on behalf of the European Geosciences Union.
BGD

$6,5461-5505,2009$

Distribution of Amazon forest structure

S. Saatchi et al.

Title Page

Abstract

Introduction

Conclusions

References

Tables

Figures

14

4

Back

Close

\section{Full Screen / Esc}

Printer-friendly Version

Interactive Discussion 


\section{Abstract}

Landscape and environmental variables such as topography, geomorphology, soil types, and climate are important factors affecting forest composition, structure, productivity, and biomass. Here, we combine a network of forest inventories with recently 5 developed global data products from satellite observations in modeling the potential distributions of forest structure and productivity in Amazonia and examine how geomorphology, soil, and precipitation control these distributions. We use the RAINFOR network of forest plots distributed in lowland forests across Amazonia, and satellite observations of tree cover, leaf area index, phenology, moisture, and topographical variations. A maximum entropy estimation (Maxent) model is employed to predict the spatial distribution of several key forest structure parameters: basal area, fraction of large trees, fraction of palms, wood density, productivity, and above-ground biomass at $5 \mathrm{~km}$ spatial resolution. A series of statistical tests at selected thresholds as well as across all thresholds and jackknife analysis are used to examine the accuracy of distriwere interpreted using soil, precipitation, and geomorphological features of Amazonia and it was found that the length of dry season played a key role in impacting the distribution of all forest variables except the wood density. Soil type had a significant impact on the wood productivity. Most high productivity forests were distributed either on less infertile soils of western Amazonia and Andean foothills, on crystalline shields, and younger alluvial deposits. Areas of low elevation and high density of small rivers of Central Amazonia showed distinct features, hosting mainly forests with low productivity and smaller trees.

\section{Introduction}

25 The Amazon forest is one of the most important bioregions of the Earth, playing a major role as a store of carbon, as an interface for the exchange of carbon, water, energy
BGD

6, 5461-5505, 2009

Distribution of Amazon forest structure

S. Saatchi et al.

Title Page

Abstract

Introduction

Conclusions

Tables

References

Figures

14

$\rightarrow$

4

Back

Close
Printer-friendly Version

Interactive Discussion 
and other biogeochemical variables, and as a host of over one quarter of the biodiversity on the planet (Terborgh and Andresen, 1998; Phillips et al., 2004; Ter Steege et al., 2006). In recent years there have been substantial advances in the understanding of the structure and functioning of Amazonia, through research programmes such 5 as the LBA (Large-Scale Biosphere-Atmosphere Programme in Amazonia; Davidson et al., 2004; Keller et al., 2004) and the RAINFOR forest inventory network (Malhi et al., 2002). However, given the vast scale, inaccessibility and poorly understood spatial heterogeneity of the Amazonian landscape, there remains a major need to understand and map the spatial variability of forest ecology and structure in Amazonian forests.

10 This need has become more pressing with recent interests in quantifying the carbon stores in tropical forests as a tool for providing economic incentives for forest conservation (Gullison et al., 2007).

Significant changes in the extent and ecology of the old-growth Amazon forests have been documented in recent years and they have been attributed largely to human15 induced impacts and climate perturbations. Deforestation and degradation had reduced the forest extent to approximately $87 \%$ of its original extent by 2001 (SoaresFilho et al., 2006). Occasional drought episodes have exacerbated the human impacts by increasing forest fires (Aragão et al., 2007). Rising temperatures and carbon dioxide concentrations may have a direct impact on the physiology, productivity and water balance of forest plant species, and affect the relative competitive advantage of different plant functional or structural types (Malhi et al., 2009). This dual threat of degradation and climate change may have long term effects on the forest structure and function by changing the mortality and growth rates of trees and increase the frequency of disturbance (Malhi et al., 2008; Phillips et al., 2008). These changes will not happen uniformly over the Amazonia, as there exist landscape or regional variations in forest composition, ecological function, and resilience (Nepstad et al., 2008; Saleska et al., 2007). However, these variations are poorly quantified and interpolations from study sites to the entire Amazonian forest biome are often hampered because of low number of plots and geographical coverage.

\section{BGD}

$6,5461-5505,2009$

Distribution of

Amazon forest structure

S. Saatchi et al.

Title Page

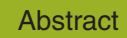

Introduction

Conclusions

Tables

References

Figures

।

$>$ I

4

Back

Close

Printer-friendly Version

Interactive Discussion 
Our overall ability to predict the spatial distributions of forest parameters at landscape scales has recently progressed considerably because of both improved spatial methods and more extensive high-quality observational records, including networks of forest plots with systematic measurements and consistent compilations in Amazonia 5 and remote sensing observations of vegetation parameters and climate (Saatchi et al., 2007; Malhi et al., 2006). However, a considerable challenge remains in inferring wider scale properties of Amazonian forests from field inventory data (which are always limited in the context of the scale of Amazonia). An idealized, information-rich interpolation scheme would combine field inventory data with remote sensing data layers, and 10 information on climate, topography, geomorphology and soil type.

In this paper, we present a new method for extrapolating the information from forest plots over Amazonia by using the Maximum-entropy (Maxent) estimation model and a suite of satellite observations of canopy cover, leaf area index, phenology, moisture, rainfall regime and surface topography. Forest structure and productivity from 226

forest plots within the RAINFOR network have been compiled to train the Maxent model and present maps of distribution of basal area, wood density, above-ground biomass, wood productivity and several forest structural parameters across Amazonia at $5 \mathrm{~km}$ spatial resolution.

\section{Materials}

\subsection{Forest plots}

We compiled data from the RAINFOR network of long-term forest monitoring plots http://www.rainfor.org; Malhi et al., 2002; Peacock et al., 2007), across South America (Table 1). Within this network considerable effort has been expended on standardization of data collection and quality control, resulting in a particularly high degree of

\section{BGD}

$6,5461-5505,2009$

Distribution of Amazon forest structure

S. Saatchi et al.

Title Page

Abstract

Introduction

Conclusions

Tables

References

Figures

14

$\rightarrow$

4

Back

Close

Printer-friendly Version

Interactive Discussion 
of variables: (i) forest structure in terms of basal area (BA), basal area fraction of large trees (BAL) with $\mathrm{DBH}$ (diameter at $1.3 \mathrm{~m}$ height) larger than $40 \mathrm{~cm}$ (a DBH of $40 \mathrm{~cm}$ is a typical minimum diameter for trees that reach the forest upper canopy), basal area fraction of individuals that are palms (BAP), and the above-ground biomass

5 from allometric equations (ii) mean stand-level wood density or specific gravity (WD), and (iii) estimates of stand-level coarse wood productivity (WP) as a measure of forest productivity (Malhi et al., 2004). The dry weight of above-ground live biomass (AGB in $\mathrm{Mg} / \mathrm{ha}$ ) for each plot was calculated for trees greater than $10 \mathrm{~cm} \mathrm{DBH}$, using established allometric equations and the mean stand-level wood density (Baker et al., 2004). 10 We present results from 135 to 226 plots, depending on available data and selection criteria for different analyses. The plots were distributed over eight countries (Bolivia, Brazil, Colombia, Ecuador, French Guiana, Guyana, Peru, and Venezuela) at elevations less than $600 \mathrm{~m}$ in lowland terra firme or flooded forests (Fig. 1). Methodological details and measurement protocols have been described elsewhere (Malhi et al., 2004;

15 Baker et al., 2004; Phillips et al., 2002; Phillips et al., 2008). Many of the plot values presented here are updated from previous publications by incorporating more recent censuses, and there are also several additional plots (RAINFOR database last access date: September 2008). The range and histograms of forest variables extracted from the forest plots are shown in Fig. 1.

\subsection{Remote sensing data}

We compiled a set of remote sensing data and products from different earth observing sensors to derive metrics sensitive to vegetation and landscape variables. The data set included both optical and microwave satellite sensors. To quantify spatial and temporal patterns in canopy structure, we used the monthly $1 \mathrm{~km}$ LAl (Leaf Area Index) data 25 derived from MODIS reflectance over the five-year period, 2000-2004 (Myneni et al., 2002). We preferred LAI to NDVI or any other vegetation index because of how it relates to canopy structure and seasonality because it has undergone various quality checks before and during LAl algorithm implementation (Myneni et al., 2002). The MODIS

\section{BGD}

6, 5461-5505, 2009

Distribution of

Amazon forest structure

S. Saatchi et al.

Title Page

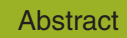

Introduction

Conclusions

Tables

References

Figures

14

I

4

Back

Close

Full Screen / Esc

Printer-friendly Version

Interactive Discussion 
8-day LAI product provided the basis and maximum compositing was applied to create the monthly LAI data layers. This step improved data quality further by reducing the impact of clouds. We produced "long-term" monthly means by averaging LAI values over five years (2000-2004) in order to attenuate any interannual signal in the record.

5 The monthly data were then used to generate five metrics: annual maximum, (Fig. 3a) minimum, mean, standard deviation, and range (difference of maximum and minimum) at $5 \mathrm{~km}$ resolution. The LAI metrics may have some value in capturing landscape scale ecosystem function and deciduousness (Myneni et al., 2007).

We also included the MODIS-derived vegetation continuous field (VCF) product as 10 a measure of the percentage of tree canopy cover within each $1 \mathrm{~km}$ pixel resolution (Hansen et al., 2002). The VCF product is generated from the time series composites of MODIS data from the year 2001 and is available from the Global Land Cover Facility at the University of Maryland. The VCF product separates open (e.g., shrub lands, savannas), fragmented, and deforested areas from those of closed forests.

15 As part of the microwave remote sensing measurements, we included global QSCAT (Quick Scatterometer) data available in three-day composites at $2.25 \mathrm{~km}$ resolution (Long et al., 2001). The three-day time series over five years (2000-2004) were used to create average monthly composites at $5 \mathrm{~km}$ resolution and then further processed to produce four metrics that included annual mean and standard deviation of radar backscatter at both $\mathrm{HH}$ and VV polarizations ( $\mathrm{H}$ : horizontal, V: vertical). QSCAT radar measurements are at $\mathrm{KU}$ band $(12 \mathrm{GHz})$ and are sensitive to surface or canopy roughness, moisture, and other seasonal attributes, such as phenological changes, although the relationship between QSCAT and specific forest variables is yet to be explored. For areas with low vegetation biomass, such as woodlands and savanna, measurements at different polarizations correlate positively with the aboveground biomass (Long et al., 2001; Saatchi et al., 2006). For areas with dense forest, backscatter measurements are sensitive to canopy roughness and moisture and contribute to measuring differences in forest types and canopy structure. The long-term (5 years) averages of MODIS and QSCAT data and the metrics used in this study are assumed to approximately repre-

BGD

$6,5461-5505,2009$

Distribution of Amazon forest structure

S. Saatchi et al.

Title Page

Abstract Introduction

Conclusions

Tables

References

Figures

14

4

Back

Close

Full Screen / Esc

Printer-friendly Version

Interactive Discussion 
sent the mean state of the environmental variables they represent (Buermann et al., 2008). In this study, we used the long term mean (Fig. 3b) and standard deviation of QSCAT HH backscatter data and excluded the VV backscatter data because of its high correlation with the $\mathrm{HH}$ backscatter over tropical forests.

\subsection{Terrain descriptors}

We added the SRTM (Shuttle Radar Topography Mission) digital elevation data, aggregated from approximately $90 \mathrm{~m}$ resolution to $5 \mathrm{~km}$, in the pool of spatial data layers (Fig. 3c). In addition to the mean elevation, the standard deviation of surface height when averaged from $90 \mathrm{~m}$ to $5 \mathrm{~km}$ was also included as a metric to represent landforms or geological features with different ruggedness or topographical variability. We used the SRTM layers along with the rest of remote sensing data, to model the distribution of forest ecological variables. The layers were also used to interpret the forest structural and productivity distributions in terms of landscape morphological characteristics such as the drainage, depositional, and sedimentary characteristics of the Amazon basin 15 (Rossetti et al., 2005; Renno et al., 2008). The standard deviation of elevation captures small and large-scale variations in the surface topography, separates the regions of river drainage from other geological surfaces, and shows the relative abundance of streams and rivers on the landscape scale.

\subsection{Precipitation}

20 We used remotely sensing-derived precipitation data from the sensors onboard the Tropical Rainfall Mapping Mission (TRMM) (Kummerow et al., 1998). The TRMM products were obtained from the global rainfall algorithm (3B43), combining the estimates from the sensors with the global gridded rain gauge data from the Climate Assessment and Monitoring System (CAMS), produced by NOAA's Climate Prediction Center and/or global rain gauge product, produced by the Global Precipitation Climatology Center (GPCC). The output is rainfall for $0.25 \times 0.25$ degree grid boxes for each month.
BGD

$6,5461-5505,2009$

Distribution of Amazon forest structure

S. Saatchi et al.

Title Page

Abstract Introduction

Conclusions

Tables References

Figures

14

$\rightarrow 1$

4

Back

Close

\section{Full Screen / Esc}

Printer-friendly Version

Interactive Discussion 
Monthly rainfall data from TRMM covering the tropical region $\left(20^{\circ} \mathrm{N}-20^{\circ} \mathrm{S}\right)$ and extended to $\left(50^{\circ} \mathrm{N}-50^{\circ} \mathrm{S}\right)$ over a period of ten years (1998-2007) were used to develop climatologically averaged precipitation metrics such as the total annual precipitation, driest quarter precipitation, wettest quarter precipitation, and seasonality (coefficient of 5 variation of precipitation) (Fig. 3d). In developing the climatological metrics, we resampled the TRMM data to $5 \mathrm{~km}$ resolution using a cubic-spline routine. The TRMM measurements are superior to interpolated precipitation fields based on rain gauges (e.g. WorldClim dataset, see Hijimans et al., 2005), because of its contiguous and extensive coverage, particularly over tropics where very few ground stations are available.

10 Overall, we included eleven data layers (2 MODIS LAI, 2 QSCAT, 1 MODIS VCF, 2 SRTM, 4 TRMM) in this study (Table 1). These layers were chosen after performing a correlation test and removing highly correlated layers (Buermann et al., 2008).

\subsection{Soil data}

We developed a soil class/landform map for the entire Amazonia to assist in the interpretation and analysis of distribution maps. The soil class data for the entire study area have been derived from two data sets:

1. Outside Brazil, the Soil and Terrain Database for Latin America and Caribbean (SOTERLAC, version 2) released in 2005 at 1:5 million scale (Dijkshoorn et al., 2005);

2. Within Brazil, the RADAMBRAZIL soil classification complied by the Instituto Brasileiro de Geografia e Estatìstica (IBGE) in 1981 (EMBRAPA, 1981).

\section{BGD}

$6,5461-5505,2009$

Distribution of

Amazon forest structure

S. Saatchi et al.

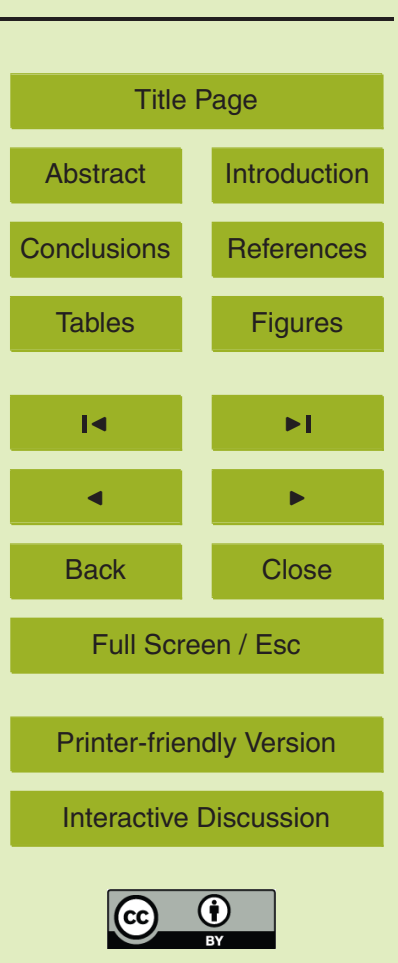


combined and simplified to create a digital soil map of Amazonia with 9 different broad categories (Fig. 4). The assignment of the soil class was based on matching the descriptions of the map units and comparing with the landforms and geographical description provided by Sombroek (2000). The categories are:

1. Heavily leached white sand soils (spodosols and spodic psamments in US Soil Taxonomy, podzols in World Reference Base (WRB) taxonomy), which predominate in the upper Rio Negro region and includes the arenosols, regosols, and podzols (category $\mathrm{Pa}$ in Sombroek, 2000).

2. Heavily weathered, ancient oxisols (ferralsols in WRB classification), which predominate in the eastern Amazon lowlands, either as Belterra clays of the original Amazon planalto (inland sea or lake sediments from the Cretaceous or early Tertiary), or fluvatile sediments derived from reworking and resedimentation of these old clays (categories A and Uf in Sombroek, 2000).

3. Less ancient oxisols and other soils (ferralsols and nitosols in WRB taxonomy), in younger soils or in areas close to active weathering regions (e.g. the Brazilian and Guyana crystalline shield) - category Uc in Sombroek (2000) and ferralsols of Brazil.

4. Less infertile lowland soils (ultisols and entisols is USDA taxonomy; cambisols and acrisols in WRB classification), which particularly predominate in the western Amazonian lowlands and some parts of Brazil, particularly on sediments derived from the Andean cordillera by fluvatile deposition in the Pleistocene or earlier (category Ua in Sombroek, 2000).

5. Alluvial deposits from the Holocene (less that 11500 years old), including very recent deposition, including the fluvisols of Brazil (category Fa in Sombroek, 2000).

6. Contemporary alluvial soils including acrisols with plinthic and gleyic content, gleysols, luvisols, histosols.

BGD

6, 5461-5505, 2009

Distribution of

Amazon forest structure

S. Saatchi et al.

Title Page

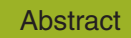

Introduction

Conclusions

References

Tables

Figures

14

$\rightarrow$

4

Back

Close

Full Screen / Esc

Printer-friendly Version

Interactive Discussion 
7. Young, submontane soils, perhaps fertilized by volcano-aeolian deposition (particularly sites in Ecuador, category Uae in Sombroek, 2000).

8. Seasonally flooded riverine soils, still in active deposition (tropaquepts), but perhaps occasionally experiencing anaerobic conditions.

9. Poorly drained lowland sites (probably histosols).

\section{Methods}

\subsection{Maximum entropy model}

We used the Maximum Entropy (Maxent) algorithm, which has been very recently introduced for modeling of species distributions (Phillips et al., 2005). Maxent is a general10 purpose algorithm that generates predictions or inferences from an incomplete set of information. The Maxent approach is based on a probabilistic framework. It relies on the assumption that the incomplete empirical probability distribution, which is based on the occurrences of the point locality of a variable on a geographical space, can be approximated with a probability distribution that has maximum entropy (the Maxent distribution) subject to certain environmental constraints, and that this distribution approximates potential geographic distribution (Jaynes, 1957; Phillips et al., 2005). For our purpose, we assume the unknown probability distribution $P$, is defined over a finite set $X$ (interpreted as the set of pixels within the study area), with the probability value of $P(x)$ for each point $x$. These probabilities sum to 1 over the space defined by $X$. 20 The Maxent algorithm approximates $\hat{P}$ by a probability distribution with the entropy of $\hat{P}$ as:

$$
\text { Entropy }=-\sum_{x \in X} \hat{P}(x) \ln [\hat{P}(x)]
$$

where $\mathrm{In}$ is the natural logarithm. Entropy is a non-negative number with the maximum value equal to the natural log of the number of pixels in $X$ and is a measure of con-

Distribution of Amazon forest structure

S. Saatchi et al.

Title Page

Abstract Introduction

Conclusions

Tables

References

Figures

14

$\rightarrow 1$

4

Back

Close

Printer-friendly Version

Interactive Discussion 
straints or choices of a probability distribution. The distribution $\hat{P}$ with highest entropy (least additional information is introduced through model assumptions), whilst still subject to constraints of our incomplete information is considered the best distribution for inference.

$5 \quad$ By using features that are continuous real-valued functions of $X$, and a set of sample points of $X$ provided by the field data, the Maxent algorithm employs likelihood estimation procedures to find probability distribution for all the points in $X$ that have similar statistics as the sample points. The features are functions with varying complexity (e.g. linear, quadratic) of the spatial environmental layers for the study area and the sample 10 points are a discrete set of training locations (the forest plots) with certain characteristics to be predicted over the entire study area. Like most maximum likelihood estimation approaches, Maxent, assumes a priori a uniform distribution and performs a number of iterations in which the weights are adjusted to maximize the average probability of the point localities (also known as the average sample likelihood), expressed as the 15 training gain (Phillips, 2005b). These weights are then used to compute the Maxent distribution over the entire geographic space. In the context of the present study, Maxent can be applied to geographic locations of forest plots, and remote sensing data to produce distributions expressing suitability (probability) of each pixel as a function of the environmental variables at that pixel. A high value of the probability function 20 at a particular pixel indicates that the pixel is predicted to have suitable condition for having similar characteristics as the training pixels (Phillips, 2005a).

Compared to other existing models, Maxent has a number of features that makes it very useful for extrapolating forest properties (Phillips et al., 2005a; Elith et al., 2006). These include a deterministic framework and, hence, stability as well as high perfor25 mance with relatively few sample points, better computing efficiency enabling the use of large-scale high-resolution data layers, continuous output from least to most suitable conditions, and ability to model complex responses to environmental variables. Most recently, the Maxent model has a built-in jackknife option, which allows the estimation of the significance of individual environmental data layers in computation of the final

\section{BGD}

6, 5461-5505, 2009

Distribution of

Amazon forest structure

S. Saatchi et al.

Title Page

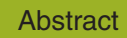

Introduction

Conclusions

Tables

References

Figures

14

I

4

Back

Close

\section{Full Screen / Esc}

Printer-friendly Version

Interactive Discussion 
distributions. The algorithm provides statistical measures for model performance such as omission rates at selected thresholds and AUC (area under the receiver operator curve), a measure of model performance across all thresholds (Phillips, 2005b). In order to convert the continuous Maxent output into a binary map that distinguishes 5 suitable from non-suitable areas an appropriate threshold can be calculated that "balances" under and over prediction based on omission rates and fractional predicted area relative to the entire study region.

\subsection{Development of distributions}

In this study, we ran the Maxent model with the location of plots from the RAINFOR net10 work. The analysis included distribution of structural and ecological variables: standlevel basal area (BA), basal area fraction of large trees (BAL), basal area fraction of palms (BAP), above-ground live biomass (AGB), mean stand-level specific gravity or wood density (WD), and the above-ground coarse wood productivity (WP). Maxent models were generated using the plot locations and the remote sensing data layers at $155 \mathrm{~km}$ spatial resolution. The model performance was examined using two indicators: the fraction of predicted area and extrinsic omission rate at a selected threshold and the AUC as a measure of model performance across all thresholds. For all model runs, AUC values ranged between 0.825 and 0.975 suggesting that the predictions were significantly better than random $(A \cup C=0.5)$, with high statistical significance (one-tailed $20 p<0.001$ ). This result was obtained for both the training localities (using $60 \%$ of forest plot localities) and the test localities (40\% of forest plots), with the small difference in AUC values suggesting a robust performance of the Maxent algorithm to capture the variations in environmental variables over the point localities. All omission tests were calculated at $10 \%$ threshold value based on Maxent's cumulative probability distribution. In all cases, the extrinsic omission rates based on the test localities were small (less than 10\%), suggesting that only a small fraction of the forest plots fell into pixels not predicted by Maxent. The overall robust model performace in the case of all forest variables implied that the Maxent-derived distributions are a close approximation of the

\section{BGD}

$6,5461-5505,2009$

Distribution of

Amazon forest structure

S. Saatchi et al.

Title Page

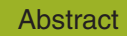

Introduction

Conclusions

Tables

References

Figures

14

-1

4

Back

Close

Full Screen / Esc

Printer-friendly Version

Interactive Discussion 
probability distributions that represent the reality. We consider results for each of the forest variables in turn.

For each analysis, we divided the variables associated with the plots into different range classes based on their cumulative probability histograms. For each class, we 5 performed a Maxent run and the corresponding continuous distribution was converted into a binary map (distinguishing suitable from non-suitable regions) through using a fixed threshold that was determined using several statistical performance measures. The final map was generated by overlaying these binary maps using the simple decision rule classifier (see Sect. 3; the detailed classification procedure is discussed in 10 Table 3).

\section{Results}

\subsection{Basal area (BA)}

A total of 226 points were used in the basal area (BA) analysis. The basal area had a unimodal (Fig. 2a) and approximately symmetric distribution with the mean value

of $28.1 \pm 5.6 \mathrm{~m}^{2}$ ha $^{-1}$ (range of $8.8-42.4$ ). We divided the basal area into 4 classes using approximately the 25 percent intervals of the cumulative probability distribution: class 1: BA $<23 \mathrm{~m}^{2} \mathrm{ha}^{-1}(N=35)$, class 2: $23<\mathrm{BA}<27 \mathrm{~m}^{2} \mathrm{ha}^{-1}(N=48)$, and class 3 : $27<\mathrm{BA}<32 \mathrm{~m}^{2} \mathrm{ha}^{-1}(N=95)$, and BA>32 $\mathrm{m}^{2} \mathrm{ha}^{-1}(N=49)$. For each of the classes, the continuous Maxent outputs were converted into binary maps and overlaid using the simple decision rule classifier (see above).

The overall distribution of basal area is highly variable because it is affected by local landscape features such as topography, geomorphology, and various types of disturbance (Fig. 5a). However, several features stand out that provide insights into regional differences of forest structure. Forests of eastern Amazonia (particularly in barada, the ridges of Serra Tumucumaque in the state of Amapa, and some areas

BGD

6, 5461-5505, 2009

Distribution of Amazon forest structure

S. Saatchi et al.

Title Page

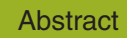

Introduction

Conclusions

Tables

References

Figures

14

$\rightarrow$

4

Back

Close

Full Screen / Esc

Printer-friendly Version

Interactive Discussion 
of the Guiana Shields in French Guiana, Surinam, and Guyana) have the highest stand level basal area $\left(B A>32 \mathrm{~m}^{2} \mathrm{ha}^{-1}\right)$. Central Amazonia has mixed patterns of medium $\left(27<\mathrm{BA}<32 \mathrm{~m}^{2} \mathrm{ha}^{-1}\right)$ to low $\left(23<\mathrm{BA}<27 \mathrm{~m}^{2} \mathrm{ha}^{-1}\right)$ basal area with areas along the southern boundaries of transitional and forest-savanna boundary dominated by 5 very low basal area $\left(B A<23 \mathrm{~m}^{2} \mathrm{ha}^{-1}\right)$. Areas in western Amazonia show two distinct patterns. There are many regions of medium-low basal area, but there appears to be a band of high basal area ranging from the lowlands of western Brazil and eastern Peru extending to western Columbia. There are also distinct patches of high basal area in southern Peru in the upper Madre de Dios and lower Ucayali basins, and within the 10 Manu National Park.

Analysis of environmental contributions and the results from jackknife test of variable importance provided the relative contribution of environmental variables for each BA class. Areas of low basal area $\left(B A<23 \mathrm{~m}^{2} \mathrm{ha}^{-1}\right)$ were separated from the rest of the forests by contributions from four variables: MODIS maximum LAI of less than 5.5

15 (47\%), SRTM elevation of $>175 \mathrm{~m}(13 \%)$, TRMM rainfall of driest quarter between 150 to $300 \mathrm{~mm}(11 \%)$, and QSCAT annual mean of less than $-8 \mathrm{~dB}(9 \%)$. For areas with higher basal area (BA>32 $\mathrm{m}^{2} \mathrm{ha}^{-1}$ ), MODIS maximum LAI (5.5-6.0), high rainfall of dry season $(>300 \mathrm{~mm})$ and low to medium SRTM surface ruggedness $(<10 \mathrm{~m})$ explained, respectively $42 \%, 24 \%$, and $13 \%$ of the spatial patterns.

\section{$20 \quad 4.2$ Fraction of large trees (BAL)}

The fraction of basal area in larger trees $(\mathrm{DBH}>40 \mathrm{~cm})$ was derived for a total of 172 plots, and was used to map the distribution of fraction of large trees in percentage (BAL) in Amazonia. BAL varied between $11-73 \%$ and had an approximately unimodal and symmetric distribution (Fig. 2) with the mean value of $43 \% \pm 11 \%$. We divided BAL 25 into four categories of BAL $<35 \%(N=31), 35 \%<B A L<45 \%(N=65), 45 \%<B A L<55 \%$ $(N=51)$, and $B A L>55 \%(N=24)$. As in the case of $B A$, the corresponding continuous Maxent distribution for each class was converted into a binary map and stacked on top of each other to yield the final BAL distribution maps.

BGD

$6,5461-5505,2009$

Distribution of Amazon forest structure

S. Saatchi et al.

Title Page

Abstract

Introduction

Conclusions

Tables

References

Figures

14

$\rightarrow 1$

4

Back

Close

Full Screen / Esc

Printer-friendly Version

Interactive Discussion 
The BAL map shows very distinct patterns and there are significant differences in details between BAL and BA distributions (Fig. 5b). Large areas in central and northwest Amazonia, close to the main stem of the Amazon River are classified as having low percentage of large trees (BAL $<35 \%$ ). Part of the southern fringe of Amazonia, along 5 the semi-deciduous and transitional forests of Bolivia and southern Brazil are also classified as $B A L<35 \%$. In contrast, areas in central-eastern Amazonia east of the confluence of the Negro and Amazon rivers, extending into the Guyanas and south-east to the lower Tapajos and Xingu rivers are classified with BAL greater than $45 \%$ and $55 \%$. Several patches of forests in southwestern Amazonia, the basins of Rio Madre - de Dios, Manu and lowland flanks of Andes in Peru and (to a lesser extent) in Ecuador also have medium $(35 \%<\mathrm{BAL}<45 \%)$ or high BAL $(>45 \%)$. Narrow upland plateaus along Amazon tributaries and in between small rivers are also classified as medium to high BAL.

The jackknife test identified MODIS maximum LAI with mean value of $5.7(41 \%)$, 15 (medium-low) rainfall of dry season with mean value of $150 \mathrm{~mm}(22 \%)$, (medium-high) SRTM surface ruggedness between 5 and $25 \mathrm{~m}$ (13\%), and (high) rainfall of wet season above $1000 \mathrm{~mm}$ with high seasonality (7\% each) as the significant variables explaining the patterns of largest BAL (BAL $>55 \%)$. The patterns of lowest BAL were determined by MODIS maximum LAI with mean value of 6.0 (53\%), (high) rainfall of dry season greater than $400 \mathrm{~mm}(13 \%)$, low rainfall seasonality (11\%), very low moisture seasonality from QSCAT std (8\%), and low SRTM elevation with mean value of $100 \mathrm{~m}(8 \%)$. In general forests with medium to high BAL $(B A L>35 \%)$ are distributed in regions with low rainfall during the dry season and a larger seasonality, but many regions with such seasonality do not possess high BAL. The northeastern region which has the highest BAL is also the region most impacted by drought associated with El Niño events. It is possible that there is a relationship between the abundance of large trees and the likelihood of occasional severe drought. However other factors such as soils or biogeographical accident may play a major role in explaining the patterns of high BAL. The northeastern forests are dominated by legumes, aand other large-tree familes. The
BGD

$6,5461-5505,2009$

Distribution of

Amazon forest structure

S. Saatchi et al.

Title Page

Abstract

Introduction

Conclusions

Tables

References

Figures

14

$\rightarrow 1$

4

Back

Close

Full Screen / Esc

Printer-friendly Version

Interactive Discussion 
SW patches may be dominated by a few large tree genera (e.g. Cedrus, Bertholettia).

\subsection{Fraction of palms (BAP)}

We used data from 138 forest plots with measurements of basal area of palms to calculate the fraction of palm basal area (BAP). The distribution of BAP values was long5 tailed with mean value of $5.3 \% \pm 6.1 \%$, median of $3 \%$ and skewness of 1.6 (Fig. 2). The data were then divided into four categories that approximately sampled the distribution at 25 percentile intervals at BAP $<1 \%(N=40), 1 \%<$ BAP $<5 \%(N=50), 5 \%<$ BAP $<10 \%$ $(N=24)$, and BAP $>10 \%(N=24)$. When the corresponding Maxent distributions were classified (see above) two distinct patterns stand out (Fig. 5c). Central Amazonia has very low palm fractions (BAP $<1 \%$ ). and Eastern Amazonia has medium low palm fraction $(\mathrm{BAP}<1 \%)$, whereas, the western and southern regions have medium to high palm fractions (BAP>5\%). (However, our plots in eastern and central Amazonia are biased towards plateaux: river valleys do have higher palm content). These distinct features were identified primarily with few remote sensing data layers including topography, maximum $L A I$, and rainfall of dry season. The patterns of low BAP (BAP $<1 \%)$ are explained by MODIS maximum LAI $<5.8(48 \%)$, SRTM surface ruggedness higher than $10 \mathrm{~m}(23 \%)$, SRTM elevation between 50-200 m (13\%), and (medium-low) TRMM rainfall of dry season less than $300 \mathrm{~m}(11 \%)$. Patterns of medium to high palm fraction (BAP $>5 \%$ ) are determined by MODIS maximum LAI>6.0 (49\%), SRTM surface ruggedness of less than $10 \mathrm{~m}(21 \%)$, and SRTM elevation of greater than $100 \mathrm{~m}(9 \%)$. TRMM rainfall of dry season and seasonality each explained about $6 \%$ of variations but with values not so different from the low BAP case. Patterns in Central Amazonia with low to medium BAP were explained by three variables: (Very low) SRTM surface ruggedness of less than $5 \mathrm{~m}(30 \%)$, MODIS maximum LAI between 5.7 and 6.2 (23\%),

Distribution of Amazon forest structure

S. Saatchi et al.

Title Page

Abstract Introduction

Conclusions

Tables References Figures

14

$\rightarrow$

4

Back

Close

Printer-friendly Version

Interactive Discussion 


\subsection{Wood density (WD)}

A total of 176 forest plots were used in the wood density (WD) analysis. We divided the plots into 5 categories to approximately sample the entire range based on 20 percent marks of cumulative probability (Fig. 2). The categories are: $5 \mathrm{WD}<0.55 \mathrm{~g} \mathrm{~cm}^{-3}(N=30), \quad 0.55<\mathrm{WD}<0.60 \mathrm{~g} \mathrm{~cm}^{-3} \quad(N=30), \quad 0.60<\mathrm{WD}<0.65 \mathrm{~g} \mathrm{~cm}^{-3}$ $(N=25), 0.65<W D<0.70 \mathrm{~g} \mathrm{~cm}^{-3}(N=44)$, and WD>0.70 $\mathrm{g} \mathrm{cm}^{-3}(N=47)$. The classification of wood density from Maxent predictions captured few regional differences (Fig. 5d). There is a distinct difference between western and eastern Amazonia. Central and Eastern Amazonia and some areas of the Guyanas are dominated by forests with high WD (>0.65). Similar patches are also found in the basins of Tapajos and Xingu towards the Amazon estuary in the state of Para. In contrast, the western forests, particularly along lowland flanks of Andes and northern Peru and Ecuadorian Amazon are predicted as low wood density (WD<0.6), with southwestern Amazonia and parts of Ecuador having very low wood density (WD<0.55). The central and central south 15 and west of Amazonia have mixed patterns. The drainage basin of Amazon west of Rio Negro extending to the border of Colombia in the north and to the state of Acre to the south are dominated by very low wood density $(\mathrm{WD}<0.55)$ except in some uplands and plateaus near river channels. However, some of the lowlands of Colombia and northeast of Peru, on the other hand, are classified as medium to high wood density (WD>0.65). Forests in the southwest of Amazonia in eastern Peru, north and southeast of Bolivia, and along the transitional forests in southern Brazil are all classified as medium wood density $(0.55<\mathrm{WD}<0.6)$. The observed patterns provide geographical detail on the the trends previously observed by Baker et al. (2004), ter Steege et al. (2006), and Malhi et al. (2006).

25 The relative contribution of environmental layers from remote sensing data and jackknife analysis showed four variables explaining the patterns of low wood density (WD<0.55). These include: MODIS maximum LAI greater than 6.0 and LAI seasonal range greater than $20 \%$ explained, respectively $60 \%$ and $12 \%$ of the patterns, annual

BGD

$6,5461-5505,2009$

Distribution of Amazon forest structure

S. Saatchi et al.

\section{Title Page}

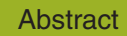

Introduction

Conclusions

Tables

References

Figures

14

$\rightarrow$

4

Back

Close 
mean and variations of QSCAT with $12 \%$ and $8 \%$, respectively. Detailed analysis of the patterns suggest that the western and southern patterns of low WD were captured with LAI metrics, whereas the patterns of central Amazonia were captured with QSCAT metrics identifying the areas of very low roughness, high moisture and very low 5 annual moisture variations typical central-western Amazonia. Forests with high wood density (WD>0.65) were classified within areas with density tree cover MODIS tree density $>90 \%$. However, the main contributions came from topographical or geological variables captured by SRTM. SRTM surface elevation and ruggedness explained $40 \%$ and $27 \%$ of the distribution, respectively. Other variables such as TRMM rainfall of dry 10 season $>200 \mathrm{~mm}$ and MODIS maximum LAI $(<6.0)$ relative contributions were $13 \%$ and $8 \%$, respectively.

\subsection{Above ground biomass (AGB)}

Above ground biomass density for 226 RAINFOR plots varied between 88 to $441 \mathrm{Mg} \mathrm{ha}^{-1}$ with a mean value of $293 \mathrm{Mg} \mathrm{ha}^{-1}$ and approximately symmetric distri15 bution (Fig. 2e). We divided the values into 5 biomass classes in $50 \mathrm{Mg} \mathrm{ha}^{-1}$ intervals: $\mathrm{AGB}<200 \mathrm{Mg} \mathrm{ha}^{-1}(N=18), 200<\mathrm{AGB}<250 \mathrm{Mg} \mathrm{ha}^{-1}(N=31), 250<\mathrm{AGB}<300 \mathrm{Mg} \mathrm{ha}^{-1}$ $(N=67), \quad 300<\mathrm{AGB}<350 \mathrm{Mgha}^{-1} \quad(N=72)$, and $\mathrm{AGB}>350 \mathrm{Mgha}^{-1} \quad(N=38)$. The biomass distribution, based on the corresponding Maxent outputs for each biomass category, show three distinguished pattern (Fig. 6):

20 1. Eastern and northeastern regions have high biomass $\left(>350 \mathrm{Mg} \mathrm{ha}^{-1}\right)$,

2. central and western regions have medium biomass (250-350 $\left.\mathrm{Mg} \mathrm{ha}^{-1}\right)$, and

3. southern and northern fringes of Amazonia have very low biomass $\left(\mathrm{AGB}<250 \mathrm{Mg} \mathrm{ha}^{-1}\right)$.

These patterns represent an optimum combination of forest structure (basal area and fraction of large trees) and wood density. The areas in eastern Brazil, along the Atlantic coast and the Guyanas have moderately high wood density and high basal

BGD

6, 5461-5505, 2009

Distribution of Amazon forest structure

S. Saatchi et al.

Title Page

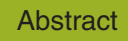

Introduction

Conclusions

Tables

References

Figures

14

> I

4

Back

Close

Full Screen / Esc

Printer-friendly Version

Interactive Discussion 
area. Heading towards the Central Amazon, biomass drops slightly to values below $300 \mathrm{Mg} \mathrm{ha}^{-1}$ in areas of higher elevation along Serra do Maicuru and Paru de Este. However, in most of eastern Amazonia and areas in both side of the Amazon river, biomass values are consistently higher than $300 \mathrm{Mg} \mathrm{ha}^{-1}$. The central region, west of

5 Rio Negro all the way to lowlands of Colombia and Ecuador, except occasional patches of low or very high biomass, stays between 300 and $350 \mathrm{Mg} \mathrm{ha}^{-1}$. The low biomass $\left(200<\mathrm{AGB}<300 \mathrm{Mg} \mathrm{ha}^{-1}\right)$ regions of western Amazonia are along the lowlands of eastern Andes from northern Peru to Bolivia. Some areas in southern Peru near Tambopata and Manu and in lowlands of Ecuador have also high biomass.

10 Jackknife analysis for relative contribution of data layers showed that areas of very low biomass ( $A G B<200 \mathrm{Mg} \mathrm{ha}^{-1}$ ) were associated with medium LAI $(70 \%)$, low rainfall of wettest quarter (15\%) and very high mean QSCAT backscatter (6\%). In contrast, the distribution of areas of high biomass (AGB>300 $\mathrm{Mgha}^{-1}$ ) was explained by low MODIS LAI (56\%), high rainfall of dry season from TRMM (17\%), and low QSCAT $15(7 \%)$. Other variables such as surface ruggedness (5\%) and low QSCAT seasonality $(5 \%)$ also contributed in defining areas of high biomass. For medium biomass areas $\left(250<\mathrm{AGB}<300 \mathrm{Mg} \mathrm{ha}^{-1}\right)$, mean QSCAT backscatter explained $51 \%$ of the distribution, followed by low rainfall of dry season with $13 \%$, and high seasonality from QSCAT standard deviation (6\%).

\subsection{Wood productivity (WP)}

We found 135 forest plots in the RAINFOR network with measurements of coarse woody production (WP) for all trees greater than $10 \mathrm{~cm}$. The values of WP are calculated from two or multiple censuses and were corrected for census intervals (Malhi et al., 2004). We used 134 plots by excluding one with very high productivity outside 25 the distribution (Fig. 7) and divided the plots into three categories representing approximately at 33 percent marks of cumulative probability: WP $<2.5(N=36), 2.5<\mathrm{WP}<3.25$ $(N=60)$, and WP>3.25 $(N=39)\left(\mathrm{MgCha}^{-1} \mathrm{yr}^{-1}\right)$. Similarly as before, the Maxent derived predictive probability for each category was converted into binary maps and

\section{BGD}

$6,5461-5505,2009$

Distribution of Amazon forest structure

S. Saatchi et al.

Title Page

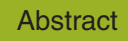

Introduction

Conclusions

Tables

References

Figures

14

$\rightarrow$

4

Back

Close

Full Screen / Esc

Printer-friendly Version

Interactive Discussion 
stacked on top of each other resulting in the final WP distribution map (Fig. 7). This distribution shows two broad regional productivity patterns as predicted from ground measurements (Malhi et al., 2004). Central and eastern Amazonia as far east as eastern Para and the Amazon estuary and as far west as the border with Colombia and

5 Venezuela are classified as areas of low productivity (WP<2.5). These two zones of medium-high productivity join up in central-eastern Amazonia, in the region between the Tapajos and Xingu rivers. The highest productivity (WP>3.25) occurs in a belt of lowland forests in the western Amazonia as far south as Santa Cruz in Bolivia, along almost the entire Peruvian lowlands to as far as Ecuador and northwestern Colombian 10 Amazon.

These broad patterns are driven with both landscape features and environmental variables. Patterns of low productivity are primarily in regions of low surface elevation and ruggedness within the drainage basin of the Amazon River, and areas with relatively low rainfall seasonality, i.e. SRTM elevation less than $150 \mathrm{~m}$ (58\%), TRMM 15 rainfall low to medium seasonality (18\%), and SRTM surface ruggedness less than $5 \mathrm{~m}$ $(14 \%)$. Areas of highest productivity (WP $>3.25$ ) were mapped using a large number of environmental variables or surface characteristics. In general, the patterns were associated with wet regions with slightly higher surface ruggedness and elevation. For the high productivity region, the jackknife test found SRTM ruggedness of greater $5 \mathrm{~m}$ explained $21 \%$ of variations and MODIS maximum LAI less than 6.0 and range of 10 $25 \%$ explained $16 \%$ and $14 \%$, respectively. SRTM elevation, at greater than $150 \mathrm{~m}$, contributed $12 \%$ to the distribution. TRMM rainfall seasonality from moderate to high values contributed about $11 \%$ to the overall distribution. Some areas in southern Amazonia in northern Bolivia and southeast of Brazil also exhibit average to high productivity (WP>2.5) and their distribution depends on a mixture of surface features and seasonality of rainfall and moisture. In addition to these broad patterns, there are several smaller and restricted patterns that are associated with areas of higher elevation in the east and northeast of Amazonia or in the foothill of Andes with elevations greater than $300 \mathrm{~m}$ and ruggedness greater than $50 \mathrm{~m}$. Below we will examine the impact of

\section{BGD}

$6,5461-5505,2009$

Distribution of

Amazon forest structure

S. Saatchi et al.

Title Page

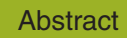

Introduction

Conclusions

Tables

References

Figures

14

$\rightarrow$ I

4

Back

Close

Full Screen / Esc

Printer-friendly Version

Interactive Discussion 
soil fertility and other landscape features to explain these patterns.

\section{Discussion}

$6,5461-5505,2009$

Using data from 226 plots distributed in Amazonia, we were able to explore the landscape scale distribution of various components of forest carbon stock and dynamics.

5 The emphasis of our study was to capture the large-scale variations in forest structure and productivity that are often known as uniform moist evergreen forests. Analysis of data from forest plots and extrapolation over the entire region resulted in two general conclusions:

1. Although there are substantial site-to-site variability among forest plots scale, we found significant regional and landscape differences.

2. The resulting patterns are complex and may show opposing or complementary trends depending on the forest parameter.

In general, we were able to find three distinct regions. The eastern lowlands and the Guyanas, have large basal area and higher fraction of large trees, higher wood density and aboveground biomass, but with low fraction of palms and low productivity. Although aboveground biomass has been determined by allometric equations using wood density and basal area, there appears to be significant landscape scale differences in their patterns. The landscape is a complex mixture of mountain slopes and vegetation types on crystalline shields and infertile soils. In contrast, in western Amazonia all the way to the eastern slopes of Andes, except for a few patches, the basal area is low with small fraction of large trees, low wood density and low-medium biomass, but with high palm fraction and wood productivity. This region is associated with undulating terrain at low altitude, rarely rising above $200 \mathrm{~m}$. Central Amazonia extending from east of Rio Negro to the border of Colombia appears like a bull-eye in most maps with medium to high basal area, low fraction of large trees, low to medium fraction of palms, high

Distribution of Amazon forest structure

S. Saatchi et al.

Title Page

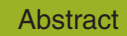

Introduction

Conclusions

Tables

References

Figures

14

$\rightarrow$ I

4

Back

Close

Full Screen / Esc

Printer-friendly Version

Interactive Discussion 
biomass, and low productivity. This region is located in low elevations (less than $100 \mathrm{~m}$ ) between Rio Negro and Solimões, is extremely wet for most of the year, and covered with recent alluvial deposits. Other regions, such as the southern reaches of Amazonia reveal typical features of transitional zones with low basal areas and aboveground 5 biomass and mixed fractions of large trees and palms, moderate wood density and productivity. In following sections, we will explore how these patterns are explained with soil, geomorphology, and climate variations in Amazonia. However, the patterns also reveal that there are large areas in Amazonia that aboveground biomass many not be consistently related to wood density or basal area. Furthermore, there are several 10 isolated features that may be related to vegetation formations and differences in architecture and floristic composition. For example, areas associated with regional centers of endemism, evolutionary barriers, floodplains, paleoclimate, geological formations, and past human disturbances can reveal distinct patterns different from regional trends (Prance, 1979; Klammer, 1980; Pires and Prance, 1985).

15 The overall patterns, however, are subject sampling bias and errors embedded in forest plots (Malhi et al., 2006). We have not removed anomalous plots with any unusual properties from our analysis. Consequently, the quantities associated with these plots have influenced the patterns at local scales. Examples of these plots are the liana-dominated, fire-affected, bamboo forests, or gallery forests among the 226 RAINFOR plots (Malhi et al., 2006). Similarly lack of sampling plots in southern transitional forests, bamboo forests of eastern Acre, or floodplains of central Amazonia has potentially introduced some errors in the overall distribution of forest structure and biomass. However, we expect these errors are largely represented in local and pixel-to-pixel variability of the distribution and less on the regional patterns.

\section{$25 \quad 5.1$ Soil type}

We overlaid forest structure, biomass and productivity distributions on the soil map and estimated the associated value of each forest parameter with the soil type normalized by area (Table 2). The standard deviation of parameters associated with each soil type

BGD

$6,5461-5505,2009$

Distribution of Amazon forest structure

S. Saatchi et al.

Title Page

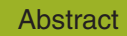

Introduction

Conclusions

Tables

References

Figures

14

4

Back

Close

Full Screen / Esc

Printer-friendly Version

Interactive Discussion 
was less than $5 \%$ of the mean (not shown). The effect of soil type on the distributions appears to be regional and at large scales. In general, the poorest soils are found in central and eastern Amazonia and the richer soils are in the west. However, results in Table 2 show that small-scale variability in distribution maps almost disappear when 5 averaged within each soil class. This is different from similar comparisons at the plot level (Malhi et al., 2004). We consider differences between the resolution of soil map and forest parameter maps as the main cause of this reduced sensitivity at the regional scale. We expect to increase the relation between soil types and forest parameters once the accuracy and resolution of soil maps improve. Nevertheless, soil types were 10 important in the distribution of forest structure and productivity.

From structural variables, BA and BAL showed less variability with soil types. In general, basal area was low in fertile soils in the western Amazonia along the Andean foothills, and on sandy soils and crystalline shield. In general ancient oxisols and some of the contemporary alluvial soil supported forests with higher basal area. Distribution of largest trees, however, corresponded with ancient oxisols primarily in eastern Amazonia and on both sides of the Amazon river. The lowest percentage of large trees were associated with areas in central Amazonia and dominated by alluvial and water-logged soils. Sandy soils and podzols in north-western Amazonia had the lowest percentage of large trees.

20 There was a significant relationship between palm fraction, BAP, and soil types. BAP on crystalline shield of southern Amazonia, less infertile soils, and Holocene alluvial deposits was almost twice the values over ancient oxisols in the east and some of the fertile lowlands of the west. BAP was found to be very low in podzols and sandy soils. However, fertile lowland soils of western Amazonia near the Andean foothills showed one of the lowest values of BAP. In general the spatial distribution of palms in western Amazonia extending from Ecuador to southern Peru and Bolivia is very heterogeneous. This heterogeneity follows an east-west gradient from very low BAP along the Andean foothills to a mixture of moderate and high BAP values in lowlands. Theere appear to be correlations between the spatial distribution of BAP and soil type. Differences in soil

BGD

$6,5461-5505,2009$

Distribution of Amazon forest structure

S. Saatchi et al.

Title Page

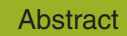

Introduction

Conclusions

Tables

References

Figures

14

I

4

Back

Close

Full Screen / Esc

Printer-friendly Version

Interactive Discussion 
type mixed with topography and other edaphic variables influence the heterogeneity and patchiness of BAP in this region. These factors also influence the composition and abundance of palms in western Amazonia (Montufar and Pintaud, 2006). Recent studies in western Amazonia suggest that plant communities, including palms tend to 5 be either uniform over large areas (Pitman et al., 2001), or heterogeneous and environmentally determined over smaller scales (Tuomisto et al., 2003). In most botanical studies, western Amazonia is considered a spatially heterogeneous region because of various recent processes (e.g. climate gradients, fluvial dynamics, tectonics) that helped shape the landscape and the soil and vegetation community.

10 Wood density (WD) appears to be distinctly lower in less infertile and fertile soils of western Amazonia and larger in ancient oxisols and alluvial deposits of central and eastern Amazonia. However, the distribution of WD does not appear to be highly dependent on soil types. In general wood density is closely related to ecological processes. Fast-growing and light-demanding species have lower wood density than shade-tolerant species (Whitmore, 1998). For example, given the relationship between the light-demanding species and the wood density, variations in disturbance due to abiotic factors such as wind patterns and storms are important in defining the mortality and recruitment of species and thus the lower wood density in western Amazonia (Chambers et al., 2004).

20 Aboveground biomass has the least relationship with the soil types in Amazonia. The fertile soils of western Amazonia have on the average 10-15\% less biomass density than other soil types in eastern and central Amazonia. As biomass is a function of both wood density and basal area, variation in biomass is determined by the factors that determine both of these component factors (Malhi et al., 2006)

25 Wood productivity has a clear relationship with soil types. Less infertile soil of western Amazonia, crystalline shield, and the younger alluvial deposits of north-western Amazonia have on the average $20-30 \%$ more productivity than the forests on old oxisols, podzols and old alluvial deposits of central and eastern Amazonia. Large homogeneous patterns derived from Maxent model for the distribution of WP (Fig. 7) is one

BGD

$6,5461-5505,2009$

Distribution of

Amazon forest structure

S. Saatchi et al.

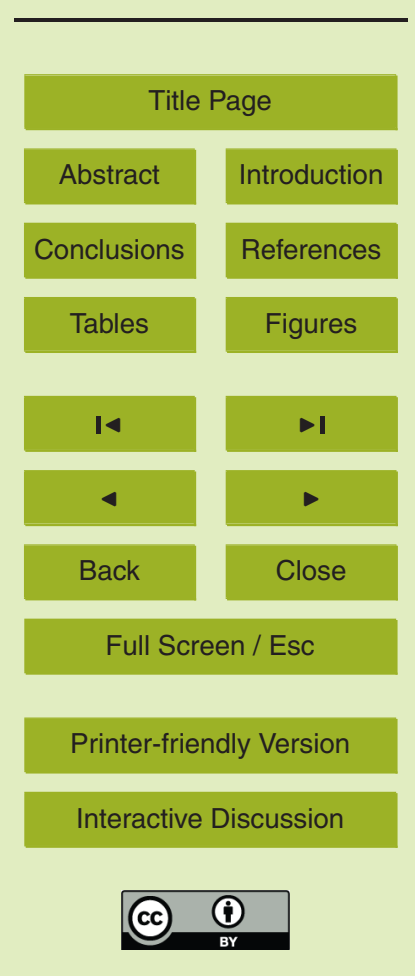


main reason that more distinctions from soil types are not present in the results shown in Table 2. These patterns are developed because of the clear influence of topography and environmental variables used as input in Maxent model. It is also possible that other soil factors such as texture and various cations may be important in determining 5 the wood productivity. Larger site-to-site variability of WP at the plot level is another indication that other factors could be important in rigorously quantifying the contribution of soil in explaining the wood productivity.

\subsection{Precipitation}

We further examined the role of climate variables in explaining the overall distribution of forest structure, biomass and productivity. The total water availability in tropical forests and the extent of dry season have been shown to be important variables in characterizing the hydraulic mechanisms underlying the forest wood production, biomass accumulation, and overall ecological function (Malhi et al., 2004; Saatchi et al., 2007; Saleska et al., 2007). Although precipitation layers were used in Maxent model runs, the overall relative contributions may have been changed after combining Maxent probabilities to generate classified distribution maps. In addition, some of the remote sensing data layers also capture aspects of surface moisture (e.g. QSCAT) and covariance among these and precipitation may obscure general pattern between rainfall and forest structure variables. We developed a new precipitation layer quantifying the length of dry 20 season (LDS) in terms of months the rainfall is less than $100 \mathrm{~mm}$ per month. This threshold has been chosen to represent the mean evapotranspiration rate of a fully wet tropical rainforest, below which the forest may experience a net water deficit (Shuttleworth, 1989; Malhi and Wright, 2004). This layer has the same spatial patterns as the total precipitation of driest quarter (Fig. 3d). By intersecting this layer and with distribution maps and calculating the area-averaged mean and standard deviation of we examined the relationship between LDS and forest parameters over Amazonia (Fig. 8). All forest parameters, except the wood productivity, showed a strong negative correlation with the months of dry season. Area-averaged basal area linearly decreased

BGD

6, 5461-5505, 2009

Distribution of Amazon forest structure

S. Saatchi et al.

Title Page

Abstract Introduction

Conclusions

Tables

References

Figures

14

$\rightarrow 1$

4

Back

Close

Printer-friendly Version

Interactive Discussion 
as LDS increased $\left(y=31.12-0.73 x, R^{2}=0.71\right)$. The relationship for BAP was slightly different. Higher values of BAL were associated more with moderate LDS than low values. Larger LDS values representing 8-10 months of dry season had much lower BAL $\left(y=38.1+3.31 x-0.36 x^{2}, R^{2}=0.86\right)$. For BAP, the variation was large, but there was 5 still a significant negative relationship with the length of dry season $(y=4.67-0.24 x$, $\left.R^{2}=0.65\right)$.

Wood density $\left(y=0.61+0.005 x-0.001 x^{2}, \quad R^{2}=0.91\right)$ and aboveground biomass $\left(y=308.1-0.34 x-0.64 x^{2}, R^{2}=0.91\right)$ both showed a strong relationship with LDS. Wood productivity, however, was weakly correlated with LDS $10\left(y=2.85+0.065 x-0.007 x^{2}, R^{2}=0.3\right)$. The insignificant contribution of LDS in determining the distribution of WP was also observed in the analysis of plot level RAINFOR data (Malhi et al., 2004).

\section{Conclusions}

In this paper, we used data on forest structure, biomass and wood productivity mea15 sured in 226 forest plots across Amazonia to develop distribution maps at $5 \mathrm{~km}$ resolution to capture the landscape scale variations. We then examined these variations against patterns of soil types, climate, and geomorphology in order to quantify important factors contributing to the heterogeneity of forests in Amazonia.

Inevitably given the paucity of ground data, any such extrapolation should still be 20 treated with caution and not be treated as a definitive spatial map until it is better evaluated. The maps will inevitably contain errors that will be reduced with incorporation of more data. Nevertheless, we believe that this exercise has generated new insights into the variation of forest structure in Amazonia, and highlighted features with distinctive structural features which may need greater sampling intensity. It has also demonstrated the utility of the Maxent method as a means of combining information from ground inventories and remote sensing layers. As such, and with appropriate caveats, we would suggest that the maps presented in our paper represent our best understanding so far

BGD

$6,5461-5505,2009$

Distribution of Amazon forest structure

S. Saatchi et al.

Title Page

Abstract

Introduction

Conclusions

Tables

References

Figures

14

$\rightarrow$

4

Back

Close

Full Screen / Esc

Printer-friendly Version

Interactive Discussion 
of the variation of forest structure across Amazonia. Such a methodology can be built upon by incorporating additional ground data, and additional satellite layers as they become available, including information on forest canopy height and canopy texture.

BGD

$6,5461-5505,2009$

Distribution of Amazon forest structure

S. Saatchi et al.

\section{Appendix A}

\section{Development of distribution maps}

10 The methodology to develop a classification of forest structure or productivity follows the steps discussed in Sect. 3.2. To clarify these steps, we demonstrate the classification procedure using a decision rule approach from Maxent model outputs. As discussed earlier, the outputs are in the form of probability of occurrence over the space defined by the environmental variables. To convert the probability values into a binary map, a suite of logistical thresholds with corresponding fractional predicted area and the omission rates are recommended by Maxent. By choosing a threshold, all areas with probability of occurrence above the threshold value can be assigned to a class.

As an example, we will use the basal area of large trees (BAL) to demonstrate the classification approach. We divided BAL into four categories of BAL (Sect. 4.2). HowBAL $>45 \%(N=75)$, and BAL $>55 \%(N=24)$. The outputs of the Maxent are continuous floating point values ranging between 0 and 1 (Fig. A1). By consulting the Maxent recommended thresholds, for each category we used a separate optimum threshold that approximately represented the minimum omission rate and the largest fractional

Title Page

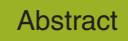

Introduction

Conclusions

Tables

References

Figures

14

$\rightarrow 1$

4

Back

Close

Full Screen / Esc

Printer-friendly Version

Interactive Discussion 
predicted area. In most cases, the 10\% threshold value based on Maxent commulative probability was chosen. In the case of BAL, we used the following thresholds to classify each category as shown in Fig. 5b.

BGD

1. $B A L<0.35 \%$, Prob $>0.496$.

2. $\mathrm{BAL}>35 \%, \operatorname{Prob}>0.331$

3. $\mathrm{BAL}>45 \%$, Prob $>0.296$

4. $B A L>55 \%$, Prob $>0.372$

We used the tree cover and a deforestation mask to separate areas of savanna vegetation and degraded landscapes. After the final map was produced, we tested 10 its accuracy by developing a confusion matrix for the percentage of points that were classified correctly in each class (Table A1). The overall accuracy remained above $90 \%$ as was predicted by the choice of the thresholds.

Acknowledgement. This paper is a product of the RAINFOR network (www.rainfor.org), which is currently supported by the Gordon and Betty Moore Foundation. This work has been per15 formed at the Oxford University Center for the Environment during a sabbatical leave from the Jet Propulsion Laboratory, California Institute of Technology and under a contract with National Aeronautic and Space Adminstration.

\section{References}

Aragao, L., Malhi, Y., Barbier, N., Anderson, L. Saatchi, S., and Shimabukuro, E.: Interactions between rainfall, deforestation and fires during recent years in the Brazilian Amazonia, Trans. Roy. Soc. Biol. Sci., 363, 1779-1785, 2008.

Baker, T.R., Phillips, O.L., Malhi, Y., et al.: Variation in wood density determines spatial patterns in Amazonian forest biomass, Global Change Biol., 10(5), 545-562, 2004.
$6,5461-5505,2009$

Distribution of Amazon forest structure

S. Saatchi et al.

Title Page

Abstract Introduction

Conclusions References

Tables Figures

14

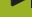

4

Back

Close

Full Screen / Esc

Printer-friendly Version

Interactive Discussion 
Buermann, W. S., Saatchi, B. R., Zutta, J., Chaves, B., Milá, C. H., Graham, and Smith, T. B.: Application of Remote Sensing Data in Predictive Models of Species' Distribution, J. Biogeogr., 35, 1160-1176, doi:10.1111/j.1365-2699.2007.01858.x, 2008.

Chambers, J. Q., Higuchi, N., Teixeira, L. M., Santos, J. D., Laurance, S. G., and Trumbore,

5 S. E.: Response of tree biomass and wood litter to disturbance in a Central Amazon forest, Oecologia, 141, 596-614, 2004.

Elith, J., Graham, C. H., Anderson, R. P., et al.: Novel methods improve prediction of species' distribution from occurrence data, Ecography 29, 129-151, 2006.

Hansen, M. C., DeFries, R., Townshend, J., Sohlberg, R., Dimiceli, C., and Carroll, M.: Towards an operational MODIS continuous field of percent tree cover algorithm: examples using AVHRR and MODIS data, Remote Sens. Environ., 83, 303-319, 2002.

IBGE (Instituto Brasileiro de Geografia e Estatìstica). Diagnûstico Ambiental da Amazonia Legal. CD-ROM produced by IBGE Rio de Janeiro, 1997.

Jaynes, E. T.: Information Theory and Statistical Mechanics, (2.2 Mb), Phys. Rev., 106, 620630, 1957.

Klammer, G.: The relief of the extra-Andean Amazon basin, In: The Amazon; limnology and landscape ecology of a mighty tropical river and its basin, edited by: Sioli, H., Dr. W. Junk Publishers, Dordrecht, Boston, Lancaster, 47-83, 1984.

Kummerow, C., Barnes, W., Kozu, T., Shiue, J., and Simpson, J.: The Tropical Rainfall Measuring Mission (TRMM) sensor package, J. Atmos. Oceanic Technol., 15, 809-817, 1998.

Long, D. G., Drinkwater, M., Holt, B., Saatchi, S., and Bertoia, C.: Global ice and land climate studies using scatterometer image data, EOS, Transaction of American Geophysical Union, 82(43), 2001.

Malhi, Y., Phillips, O. L., Baker, T., Almeida, S., Fredericksen, T., Grace, J., Higuchi, N., Killeen, T., Laurance, W. F., Leano, C., Lloyd, J., Meir, P., Monteagudo, A., Neill, D., Nunez, P. V., Panfil, S. N., Pitman, N., Rudas, A., Salomao, R., Saleska, S., Silva, N., Silveira, M., Sombroek, W. G., Valencia, R., Vieira, I., and Vinceti, B.: An international network to understand the biomass and dynamics of Amazonian forests (RAINFOR), J. Veg. Sci. 13, 439-450, 2001.

30 Malhi, Y., Baker, T. R., Phillips, O. L., et al.: The above-ground coarse wood productivity of 104 neotropical forest plots, Global Change Biol., 10(5), 563-591, 2004.

Malhi, Y. and Wright, J.: Spatial patterns and recent trends in the climate of tropical forest regions, Philos. Trans. R. Soc. London, Series B Biol. Sci., 359, 311-329, 2004.

BGD

$6,5461-5505,2009$

Distribution of

Amazon forest structure

S. Saatchi et al.

Title Page

Abstract

Introduction

Conclusions

Tables

References

Figures

14

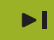

4

Back

Close

Full Screen / Esc

Printer-friendly Version

Interactive Discussion 
Malhi, Y., Wood, D., Baker, T. R., et al.: The regional variation of aboveground live biomass in old-growth Amazonian forests, Global Change Biol., 12(7), 1107-1138, 2006.

Malhi, Y., Betts, R., and Roberts, T.: "Climate change and the fate of the Amazon", compiled by: Malhi, Y., Betts, R., and Roberts, T., Special Issue of the Philosophical Transactions of the Royal Society, 363(1498), 27 May, 2008.

Malhi, Y, Aragão, L. E. O., Fisher, R. A., Galbraith, D., Huntingford, C., McSweeney, C., New, M., Sitch, S., and Zelazowski, P.: A tipping point in the Amazon? Exploring the likelihood and mechanism of a climate-change induced dieback of the Amazon rainforest, Proc. Nat. Acad. Sci., in press, 2009.

10 Montufar, R. and Pintaud, J. C.: Variation in species composition, abundance and microhabitat preferences among western Amazonian terra firme palm communities, Botanical J. Linn. Soc., 151, 127-140, 2006.

Myneni, R. B., Hoffman, S., Knyazikhin, Y., et al.: Global products of vegetation leaf area and fraction absorbed PAR from year one of MODIS data, Remote Sens. Environ., 83, 214-231, 152002.

Myneni, R. B., Yang, W., Nemani, R. R., Huete, A. R., Dickinson, R. E., Knyazikhin, Y., et al.: Large seasonal swings in leaf area of Amazon rainforests, Proceeding of National Academy of Sciences, 104, 4820-4823, 2007.

de Negreiros, G. H. and Nepstad, D. C.: Mapping deeply rooting forests of Brazilian Amazonia with GIS. Proceedings of ISPRS Commission VII Symposium - Resource and Environmental Monitoring, Rio de Janeiro, 7(a), 334-338, 1994.

Nelson, B. W.: Forest biomass inventories were conducted in Septemeber/October, 1998 in the state of Acre in the western Amazon basin Forest structure Data were collected in 05 ha plots in bamboo-dominated forest (tabocal) and forests without bamboo, 1998.

Nelson, B. W., Mesquita, R., Pereira, J. L. G., de Souza, S. G. A., Batista, G. T., and Couto, L. B.: Allometric regressions for improved estimate of secondary forest biomass in the central Amazon, Forest Ecol. Manage., 117, 149-167, 1999.

Nepstad, D. C., Stickler, C. M., Filho, B. S., and Merry, F.: Interactions among Amazon land use, forests and climate: prospects for a near-term forest tipping point, Phil. Trans. R. Soc.

$30 \quad$ B, 363, 1737-1746, doi:10.1098/rstb.2007.0036, 2008.

Peacock, J., Baker, T. R., Lewis, S. L., Lopez-Gonzalez, G., and Phillips, O. L.: The RAINFOR database: Monitoring forest biomass and dynamics, J. Veg. Sci., 18, 535-542, 2007.

Philips, S., Anderson, R. P., and Schapire, R. E.: Maximum entropy modelling of species geo-

Distribution of

Amazon forest structure

S. Saatchi et al.

Title Page

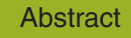

Introduction

Conclusions

Tables

References

Figures

14

$\rightarrow 1$

4

Back

Close

Full Screen / Esc

Printer-friendly Version

Interactive Discussion 
graphic distributions, Ecol. Model., 190, 231-259, 2005a.

Phillips, O. L., Lewis, S. L., Baker, T. R., Chao, K.-J., and Higuchi, N.: The changing Amazon forest, Phil. Trans. R. Soc. B, 363, 1819-1827, doi:10.1098/rstb.2007.0033, 2008.

Pitman, N. C. A., Terborgh, J., Silman, M. R., Núñez, P. V., Neill, D. A., Cerón, C. E., Palacios, W. A., and Aulestia, M.: 2001. Dominance and distribution of tree species in upper Amazonian terra firme forests, Ecology, 82(8), 2101-2117, 2008.

Pitman, N. C. A., Terborgh, J., Silman, M. R., and Nunez, P. V.: Tree species distributions in an upper Amazonian forest, Ecology, 80(8), 2651-2661, 1999.

Pires, J. M. and Prance, G. T.: The vegetation types of the Brazilian Amazon, in: Key Environments: Amazonia, edited by: Prance, G. T. and Lovejoy, T. E., Pergamon Press, New York, 442, 109-145, 1985.

Prance, G. T.: Notes on the Vegetation of Amazonia III The terminology of Amazonian forest types subject to inundation, Brittonia, 31(1), 26-38, 1979.

Prance, G. T.: American tropical forests, in: Tropical Rain Forest Ecosystems: Ecosystems 15 of the World 14B, edited by: Lieth, H. and Werger, M. J. A., Elsevier, Amsterdam, The Netherlands, 99-132, 1989.

Rennó, C. D., Nobre, A. D., Cuartas, L. A., Soares, J. V., Hodnett, M. G., Tomasella, J., and Waterloo, M.: Hand, a new terrain descriptor using SRTM-DEM: Mapping terra-firme rainforest environments in Amazonia, Remote Sens. Environ., 112, 3469-3481, 2008.

20 Rossetti, D. F., Toledo, P. M., and Goes, A. M.: New geological framework for Western Amazonia (Brazil) and implications for biogeography and evolution, Quaternary Res., 63, 78-89, 2005.

Saatchi, S., Buermann, W., Mori, S., and ter Steege, H.: Modeling distribution of Amazonian tree species and diversity using remote sensing measurements, Remote Sens. Environ., 112(5): 2000-2017, 2008.

Saatchi, S. S., Houghton, R. A., Dos Santos Alvala, R. C., Soares, J. V., and Yu, Y.: Distribution of aboveground live biomass in the Amazon Basin, Global Change Biol., 13, 816-837, 2007.

Salati, E. and Marques, J.: Climatology of the Amazon Basin, in The Amazon: Limnology and Landscape Ecology of a Mighty Tropical River and Its Basin, edited by: Sioli, H., Monographiae Biologicae, Vol. 56, Dr. W. Jumk Publishers, Dordrecht, 1984.

30 Saleska, S. R., Didan, K., Huete, A. R., and da Rocha, H. R.: Amazon forests green-up during 2005 drought, Science, 318, 612, doi:10.1126/science.1146663, 2007.

Shttleworth, W. J.: Micrometeorology of temperate and tropical forest, Philos. Trans. R. Soc. London B., 324, 299-334, 1989.

BGD

$6,5461-5505,2009$

Distribution of

Amazon forest structure

S. Saatchi et al.

Title Page

Abstract

Introduction

Conclusions

References

Tables

Figures

14

-1

4

Back

Close

Full Screen / Esc

Printer-friendly Version

Interactive Discussion 
Silman, M. R.: Provided biomass plot data over lowland terra firme and floodplain forests of Peru, Colombia, and Ecuador in 2001. For more information refer to publications at http: //www.wfu.edu/academics/biology/faculty/silman.htm, 2001.

Simard, M., Saatchi, S., and De Grandi,G. F.: The use of decision tree and multiscale texture for classification of JERS-1 SAR data over tropical forest, IEEE Trans. Geosci. Remote Sens., 38, 2310-2321, 2000.

Simard, M., De Grandi, F., Saatchi, S., and Mayaux, P.: Mapping tropical coastal vegetation using JERS-1 and ERS-1 radar data with a decision tree classifier, Int. J. Remote Sens., 23(7), 1461-1474, 2001.

10 Sombroek, W.: Amazon landforms and soils in relation to biological diversity, A. Amazonica, 30, 81-100, 2000.

Veloso, H. P., Rangel Filho, A. L. R., and Lima, J. C. A.: Classificâo da Vegetâo Brasileira, Adaptada a um Sistema Universal. IBGE, Rio de Janeiro, 1991.

Terborgh, J. and Andresen, E.: The composition of Amazonian forests: patterns at local and regional scales, J. Trop. Ecol., 14, 645-664, 1998.

Tuomisto, H., Poulsen, A. D., Ruokolainen, K., Morgan, R. C., Quintana, C., Celi, J., and Canas, G.: Linking floristic patterns with soil heterogeneity and satellite imagery in Ecuadorian Amazonia, Ecol. Appl., 13, 352-371, 2003.

Whitmore, T. C.: An Introduction to Tropical Rain Forests. Oxford University Press, 1998.

Wright, S.: Phenological responses to seasonality in tropical forest plants. In: Tropical Forest Plant Ecophysiology, edited by: Stephen, S. M., Robin, L. C. and Alan, P. S., Chapman and Hall, New York, 440-460, 1996.

BGD

6, 5461-5505, 2009

Distribution of Amazon forest structure

S. Saatchi et al.

Title Page

Abstract Introduction

Conclusions References

Tables

Figures

14

$\rightarrow 1$

4

Back

Close

Full Screen / Esc

Printer-friendly Version

Interactive Discussion 
BGD

$6,5461-5505,2009$

Distribution of Amazon forest structure

S. Saatchi et al.

\begin{tabular}{|c|c|c|c|c|c|c|c|c|}
\hline \multirow{2}{*}{$\begin{array}{l}\text { Layer } \\
\text { Number }\end{array}$} & \multirow[t]{2}{*}{ Data Record } & \multirow[t]{2}{*}{ Instrument } & \multirow[t]{2}{*}{ Ecological variable } & \multicolumn{3}{|c|}{ Data Range } & \multirow{2}{*}{$\begin{array}{l}\text { Temporal } \\
\text { Coverage }\end{array}$} & \multirow{2}{*}{$\begin{array}{l}\text { Native } \\
\text { Resolution }\end{array}$} \\
\hline & & & & Low & Medium & High & & \\
\hline 1 & Maximum Annual LAI & MODIS & $\begin{array}{l}\text { Vegetation phenology, struc- } \\
\text { ture, and net primary produc- } \\
\text { tivity }\end{array}$ & $4.5-5.5$ & $5.5-6.0$ & $6.0-6.5$ & $\begin{array}{l}2000- \\
2004\end{array}$ & $\begin{array}{l}1 \mathrm{~km} \mathrm{\&} \\
8 \text { day }\end{array}$ \\
\hline 2 & LAI Annual Range & & & $10-20 \%$ & $20-20 \%$ & $>30 \%$ & & \\
\hline 3 & Percent Tree Cover & MODIS & $\begin{array}{l}\text { Forest cover and heterogene- } \\
\text { ity }\end{array}$ & $60-70 \%$ & $70-80 \%$ & $>80 \%$ & 2001 & $1 \mathrm{~km}$ \\
\hline 4 & Annual Mean HH Backscatter & QSCAT & $\begin{array}{l}\text { Surface (canopy) moisture } \\
\text { and roughness (forest struc- } \\
\text { ture) }\end{array}$ & $<-8.0 \mathrm{~dB}$ & $(-8.0)-(-7.5) \mathrm{dB}$ & $>-7.5 \mathrm{~dB}$ & $\begin{array}{l}2000- \\
2004\end{array}$ & $\begin{array}{l}2.25 \mathrm{~km} \mathrm{\&} \\
3 \text { day }\end{array}$ \\
\hline 5 & Annual STD HH Backscatter & & & $<15 \%$ & $15-20 \%$ & $>20 \%$ & & \\
\hline 6 & DEM, Average Elevation & SRTM & Topography and ruggedness & $<75 \mathrm{~m}$ & $75-175 m$ & $>175 \mathrm{~m}$ & 2000 & $90 \mathrm{~m}$ \\
\hline 7 & $\begin{array}{l}\text { Ruggedness (standard devia- } \\
\text { tion of elevation) }\end{array}$ & & & $<5 \mathrm{~m}$ & $5-10 m$ & $>10 \mathrm{~m}$ & & \\
\hline 8 & Annual rainfall & & & $<2250 \mathrm{~mm}$ & $2250-2750 \mathrm{~mm}$ & $>2750 \mathrm{~mm}$ & & \\
\hline 9 & $\begin{array}{l}\text { Rainfall Seasonality (coeffi- } \\
\text { cient of Variation) }\end{array}$ & TRMM & Monthly Rainfall & $<7 \%$ & $7-10 \%$ & $>10 \%$ & $1998-2007$ & $0.25 \times 0.25 \mathrm{deg}$ \\
\hline 10 & Rainfall of driest quarter & & & $<150 \mathrm{~mm}$ & $150-300 \mathrm{~mm}$ & $>300 \mathrm{~mm}$ & & \\
\hline 11 & Rainfall of wettest quarter & & & $<800 \mathrm{~mm}$ & $800-950 \mathrm{~mm}$ & $>950 \mathrm{~mm}$ & & \\
\hline
\end{tabular}

Table 1. Overview of remote sensing data sets used in the Maxent predictions along with their native resolution and ecological interpretation, and range over lowland forests of Amazonia. 
BGD

$6,5461-5505,2009$

\section{Distribution of Amazon forest structure}

Table 2. Forest structure, biomass and wood productivity averaged within soil groups in Amazonia showing area-weighted means.

\begin{tabular}{lcccccc}
\hline Soil Type & BA m$~_{2} \mathrm{ha}^{-1}$ & BAL $\%$ & BAP $\%$ & WD g cm$^{-3}$ & AGB Mg ha & WP MgC ha $^{-1} \mathrm{yr}^{-1}$ \\
\hline Sandy Soil & 27.6 & 40.5 & 2.39 & 0.59 & 282.8 & 2.89 \\
Less Ancient Oxisols & 28.2 & 45.2 & 3.87 & 0.61 & 298.3 & 2.99 \\
Ancient Oxisols & 28.7 & 49.3 & 3.30 & 0.64 & 295.9 & 2.65 \\
Less Infertile Soil & 26.9 & 44.1 & 5.48 & 0.57 & 282.5 & 3.33 \\
Holocene Alluvial Deposits & 28.1 & 41.7 & 5.78 & 0.60 & 305.9 & 3.04 \\
Young Alluvial Deposits & 30.3 & 41.9 & 5.00 & 0.61 & 308.2 & 3.20 \\
Contemporary Alluvial Deposits & 30.1 & 45.4 & 4.60 & 0.61 & 310.8 & 3.08 \\
Old Alluvial Deposits & 28.4 & 41.2 & 2.50 & 0.62 & 297.2 & 2.58 \\
Fertile Lowland West & 24.8 & 45.1 & 2.62 & 0.57 & 274.1 & 3.10 \\
Fertile Lowland East & 25.2 & 45.3 & 3.16 & 0.58 & 278.5 & 3.02 \\
Crystalline Shield & 27.1 & 44.7 & 6.58 & 0.59 & 298.7 & 3.41 \\
Podzols & 29.9 & 35.4 & 2.58 & 0.62 & 295.4 & 2.72 \\
\hline
\end{tabular}

S. Saatchi et al.

Title Page

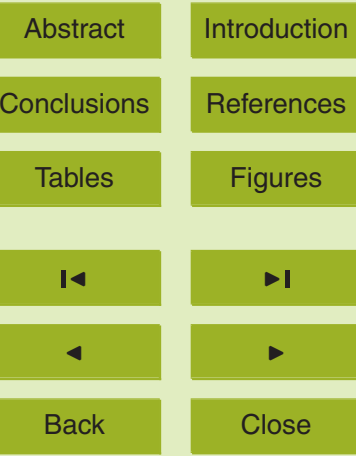

Full Screen / Esc

Printer-friendly Version

Interactive Discussion 
BGD

$6,5461-5505,2009$

Distribution of Amazon forest structure

S. Saatchi et al.

Table A1. Classification confusion matrix for the BAL map calculated by computing the number of points that are not classified accurately in each BAL class category.

\begin{tabular}{lcccc}
\hline BAL Classes & $\mathrm{BAL}<35 \%$ & $35 \%<\mathrm{BAL}<45 \%$ & $45 \%<\mathrm{BAL}<55 \%$ & $\mathrm{BAL}>55 \%$ \\
\hline $\mathrm{BAL}<35 \%(N=31)$ & 31 & 0 & 0 & 0 \\
$35 \%<\mathrm{BAL}<45 \%(N=65)$ & 0 & 60 & 5 & 0 \\
$45 \%<\mathrm{BAL}<55 \%(N=51)$ & 0 & 2 & 48 & 1 \\
$\mathrm{BAL}>55 \%(N=24)$ & 0 & 0 & 4 & 20
\end{tabular}

Full Screen / Esc

Printer-friendly Version
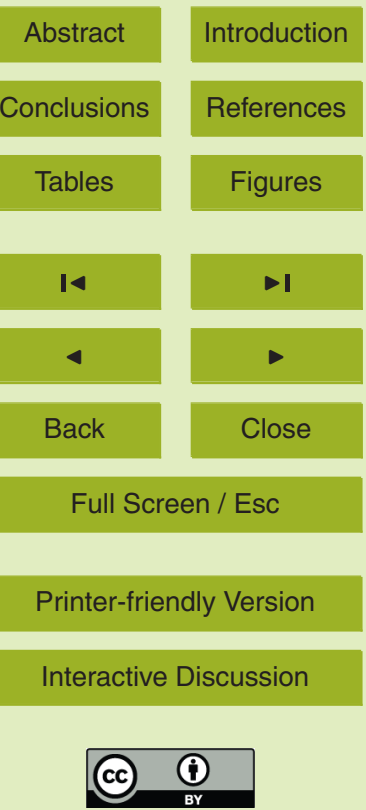
BGD

6, 5461-5505, 2009

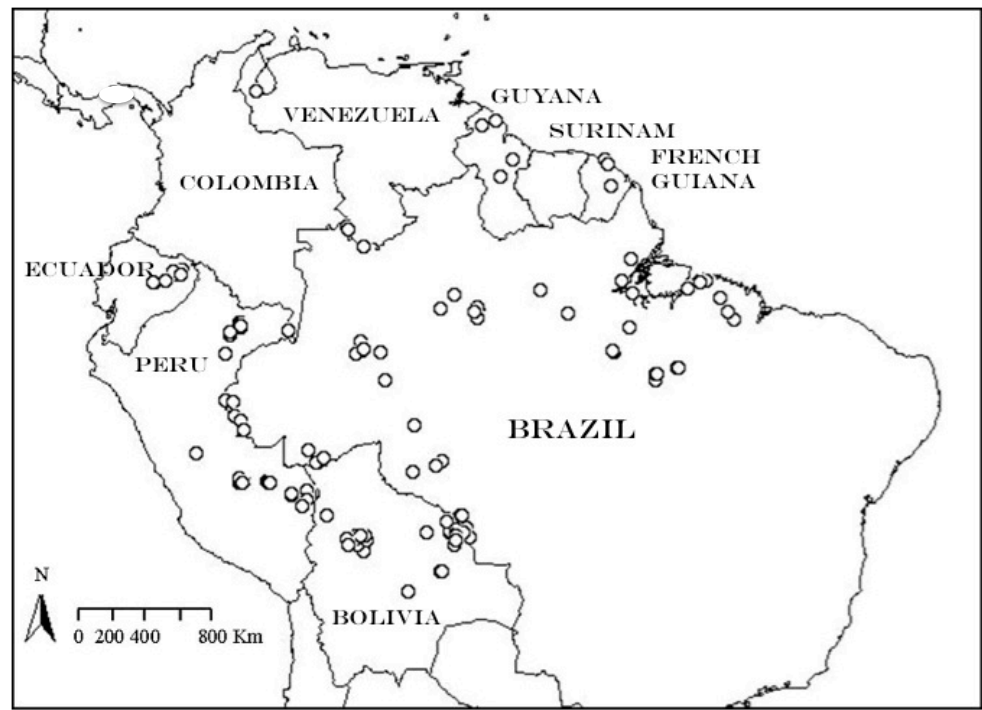

Distribution of Amazon forest structure

S. Saatchi et al.

Title Page

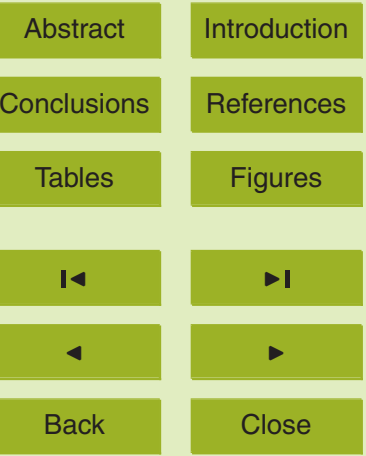

Full Screen / Esc

Printer-friendly Version

Interactive Discussion 
BGD

$6,5461-5505,2009$

Distribution of Amazon forest structure

S. Saatchi et al.

Title Page
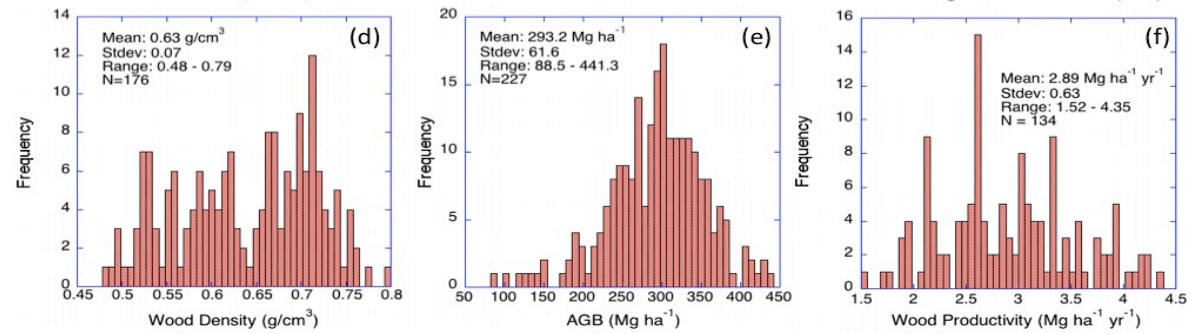

Fig. 2. Histogram of forest plot data used in this study: (a) basal area (BA) in $\mathrm{mha}^{-1}$, (b) basal area fraction of lager trees (BAL), basal area fraction of Palms (BAP), wood density (WD) in $\mathrm{g} \mathrm{cm}^{-3}$, above ground biomass (AGB) in $\mathrm{Mg} \mathrm{ha}^{-1}$, and wood productivity (WP) in $\mathrm{MgCha}{ }^{-1} \mathrm{yr}^{-1}$.

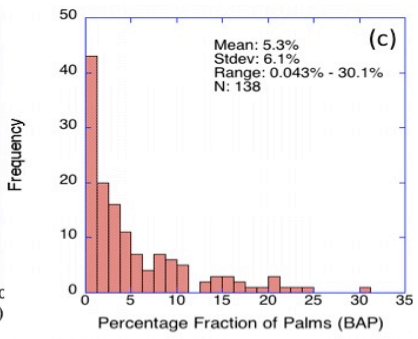

-



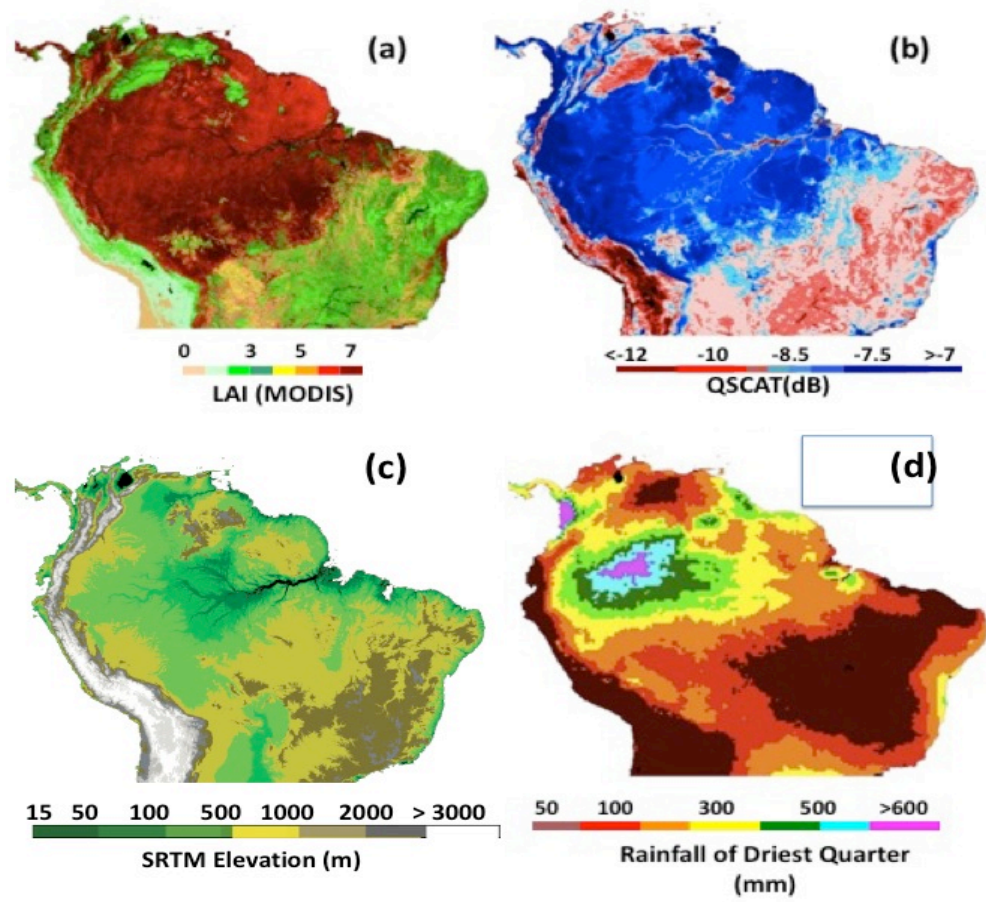

Fig. 3. A selection of spatial data layers derived from remote sensing measurements and GIS information: (a) MODIS derived maximum annual LAI, (b) QSCAT annual mean backscatter at horizontal polarization, (c) SRTM Elevation, and (d) average precipitation of driest quarter derived from TRMM.
BGD

$6,5461-5505,2009$

Distribution of Amazon forest structure

S. Saatchi et al.

Title Page

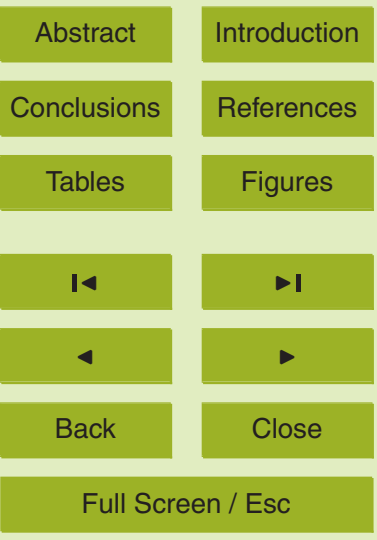

Printer-friendly Version

Interactive Discussion 
BGD

6, 5461-5505, 2009

\section{Distribution of} Amazon forest structure

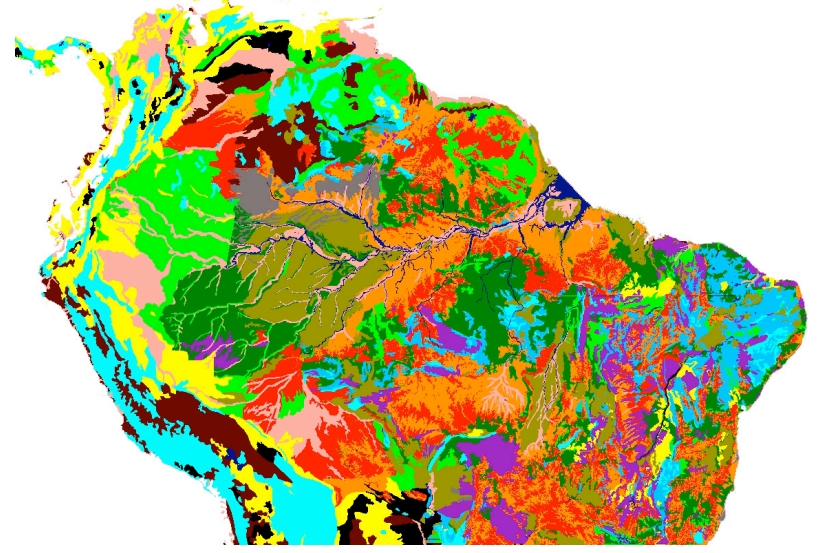

Soil Type

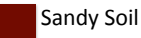

Ancient oxisols

less ancient oxisols

Less infertile lowlands

Holocene alluvial deposits

Young alluvial deposits

contemporary alluvial deposits

Old alluvial deposits

Fertile Lowlands

Crystaline Shield

others

Fig. 4. Soil map of Amazonia derived from SOTERLAC of South America and IBGE soil map of Brazil.
S. Saatchi et al.

Title Page

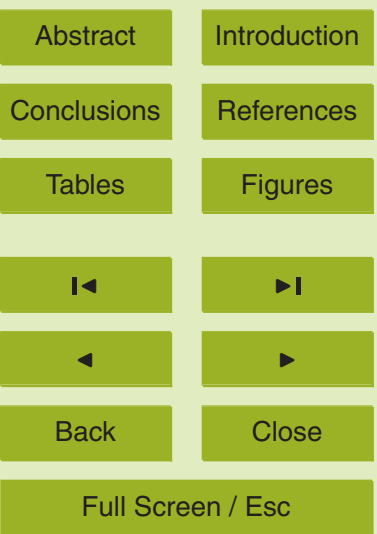

Printer-friendly Version

Interactive Discussion 
BGD

6, 5461-5505, 2009

Distribution of Amazon forest structure

S. Saatchi et al.

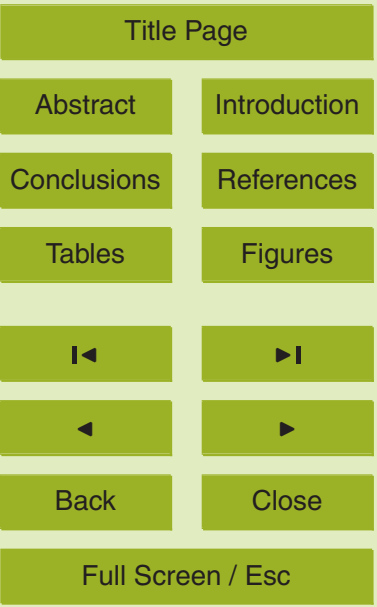

Printer-friendly Version

Interactive Discussion 
BGD

6, 5461-5505, 2009

Distribution of Amazon forest structure

Aboveground Biomass (AGB)

Nonforest/Savanna

Low AGB/Degraded

AGB $<200 \mathrm{Mg}^{-1}$

$200<$ AGB $<250 \mathrm{Mg} \mathrm{ha}^{-1}$

$250<$ AGB $<300 \mathrm{Mg} \mathrm{ha}^{-1}$

$300<$ AGB $<350 \mathrm{Mg} \mathrm{ha}^{-1}$

AGB $>350 \mathrm{Mg} \mathrm{ha}^{-1}$

Fig. 6. Distribution of aboveground biomass (AGB) from classification of Maxent model predictions using 226 RAINFOR plots and environmental variables.
S. Saatchi et al.

Title Page

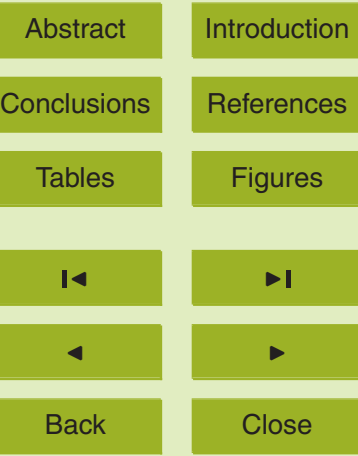

Full Screen / Esc

Printer-friendly Version

Interactive Discussion 
BGD

$6,5461-5505,2009$

Distribution of Amazon forest structure

Wood Productivity (WP)

Nonforest/Savanna

Low BA/Degraded

WP $<2.5 \mathrm{MgC} \mathrm{ha}^{-1} \mathrm{yr}^{-1}$

$2.5<$ WP $<3.25 \mathrm{MgC} \mathrm{ha}^{-1} \mathrm{yr}^{-1}$

WP > 3.25 MgC ha-1 $\mathrm{yr}^{-1}$

Fig. 7. Distribution of coarse wood productivity (WP) derived from Maxent model predictions based on 135 forest plots in RAINFOR network.
S. Saatchi et al.

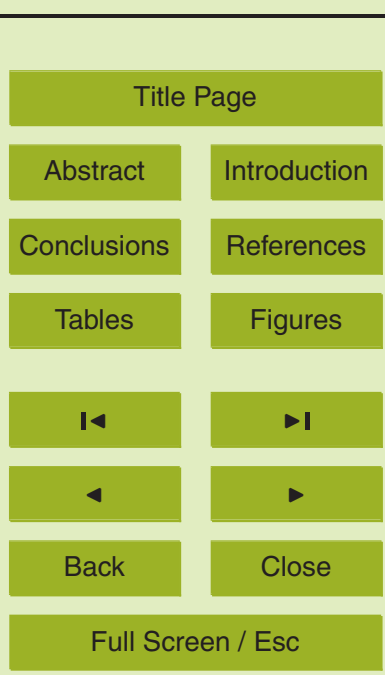

Printer-friendly Version

Interactive Discussion 

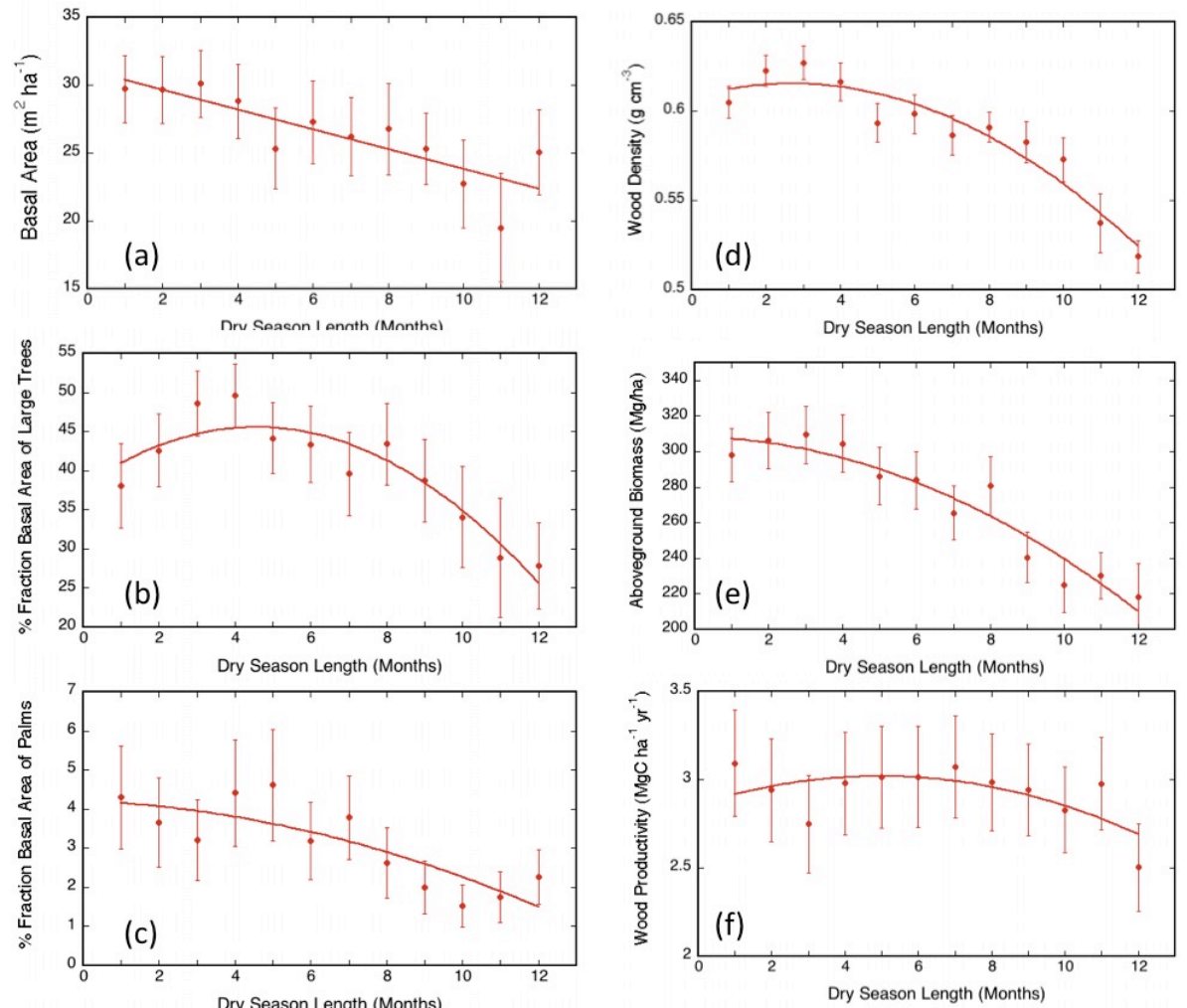

Fig. 8. Relationship between length of dry season and forest parameters over Amazonia: (a) basal area (BA), (b) fraction basal area of large trees (BAL), (c) fraction basal area of palms (BAP), (d) wood density (WD), (e) aboveground biomass (AGB), and (f) wood productivity (WP).
BGD

$6,5461-5505,2009$

Distribution of Amazon forest structure

S. Saatchi et al.

Title Page

Abstract

Introduction

Conclusions

References

Tables

Figures

14

4

Back

Close

\section{Full Screen / Esc}

Printer-friendly Version

Interactive Discussion 


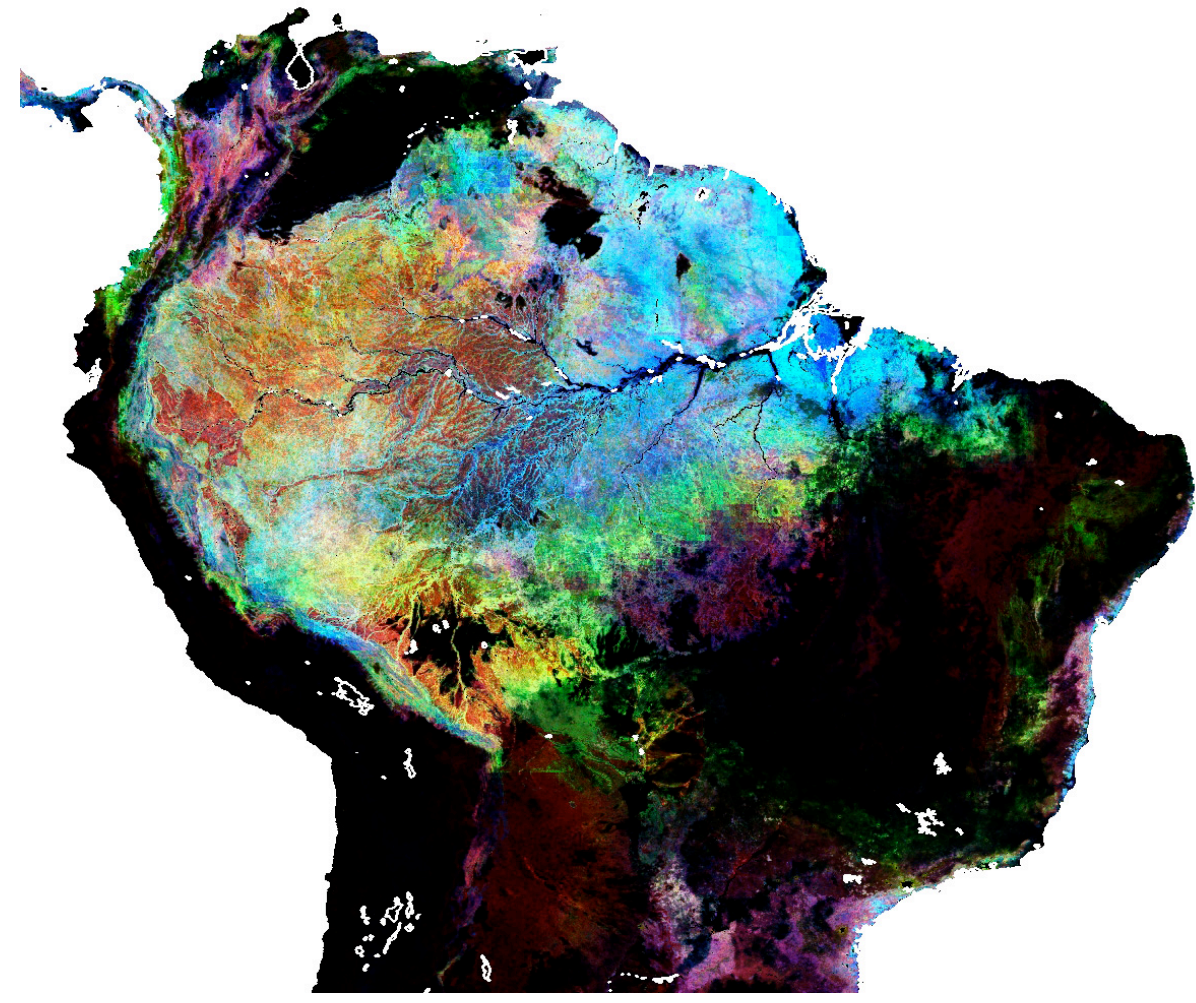

Fig. A1. Color composite of Maxent probability distributions of basal area fraction of large trees (BAL) over the Amazon basin: Red: BAL $<35 \%$, Green:BAL $>35 \%$, and Blue:BAL $>55 \%$. The probability values are continuous variables ranging between 0 and 1 .
BGD

$6,5461-5505,2009$

Distribution of Amazon forest structure

S. Saatchi et al.

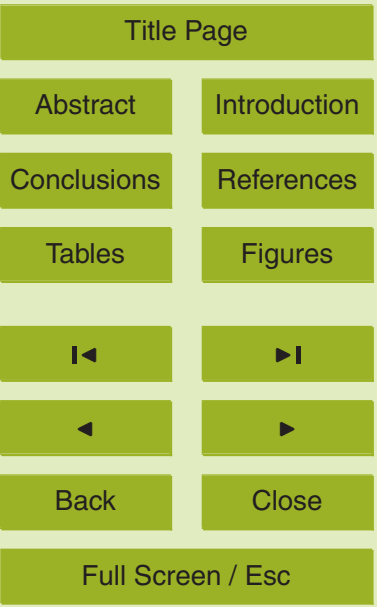

Printer-friendly Version

Interactive Discussion 